\title{
Para Além da Sociologia da Inautenticidade? Um Diálogo com Jessé Souza
}

\section{Introdução}

Desde a publicação de A modernização seletiva (2000) Jessé Souza tem realizado um esforço sistemático ${ }^{2}$ para construir uma reinterpretação do processo de modernização e da profunda desigualdade social brasileira. O sociólogo tem como objetivo construir uma verdadeira teoria crítica sobre o Brasil moderno (Souza, 2018). Suas teses vão de encontro às interpretações culturalistas de Sérgio Buarque de Holanda, Roberto DaMatta e Raymundo Faoro, que defendem, cada qual ao seu modo, que teríamos na herança ibérica pré-moderna um traço essencial e estruturante que explicaria nossos conflitos sociopolíticos principais.

Como defende Bastos (2013), o elemento mais importante presente no pensamento social brasileiro é o tema do atraso. Por conta disso, o Brasil seria marcado por um déficit de modernidade, uma vez que teríamos como elementos explicativos centrais categorias

1 Professor do Instituto Federal de Educação, Ciência eTecnologia Fluminense (IFF), campus Campos Centro, Campos dos Goytacazes, RJ, Brasil. E-mail: <olamarcos@yahoo.com.br>

2 É importante frisar que o primeiro trabalho em que Jessé Souza produz uma análise crítica sobre as interpretações que ele caracteriza como sociologia da inautenticidade é o artigo A ética protestante e a ideologia do atraso brasileiro, publicado em 1998, e que se coloca como uma continuação do artigo de Luiz Werneck Vianna, Weber e a Interpretação do Brasil. O artigo de Werneck Vianna influenciou diretamente a leitura que o sociólogo realiza dos autores que utilizam a sociologia da dominação weberiana, sobretudo o conceito de patrimonialismo, para caracterizar o atraso brasileiro. O trabalho ainda influenciou diretamente a leitura distorcida que Souza realiza da obra de Maria Sylvia de Carvalho Franco, uma vez que esta reproduziria uma leitura similar à realizada por Florestan Fernandes sobre o Brasil escravista. 
como patrimonialismo e personalismo. Assim, reproduziríamos uma formação incompleta ${ }^{3}$ quando comparados aos países centrais.

Segundo Villas Bôas (2006, p. 167), as interpretações contemporâneas têm no entrelaçamento entre condutas tradicionais e modernas o caminho para explicar os dilemas contemporâneos como a cidadania, a democracia e a violência que, por sua vez, demonstrariam a força explicativa de conceitos como patriarcalismo, mandonismo e patrimonialismo. O Brasil contemporâneo, portanto, não teria conseguido diferenciar funcionalmente Estado, economia e sociedade para que eles pudessem ser desenvolvidos a partir de lógicas e códigos próprios (Martins, 2014, p. 591).

Na mesma linha de Bastos e Villas Bôas, Lynch (2016) argumenta que o pensamento político brasileiro tem como questões centrais analisar o atraso da periferia e sua especificidade. Esta maneira de nos interpretar está relacionada com a internalização e a naturalização do atraso e da subalternidade (Lynch, 2016). Assim, os conflitos brasileiros ainda permaneceriam estruturados por elementos pré-modernos responsáveis pela singularidade e, consequentemente, pelas diferenças essenciais que existiriam entre os países centrais e o Brasil.

O trabalho de Souza foi fundamental para demarcar a insuficiência das interpretações produzidas pela sociologia da inautenticidade de Holanda, DaMatta e Faoro, através da definição dos pressupostos e das limitações existentes nas leituras culturalistas e essencialistas do Brasil. Conjuntamente, o sociólogo produziu uma teorização alternativa para defender o caráter estritamente moderno dos dilemas brasileiros, uma vez que a hierarquia social e sua legitimação tem um mecanismo de reprodução semelhante no centro e na periferia, que são os capitais econômico e cultural (Souza, 2018). Estes capitais seriam responsáveis por hierarquizar toda sociedade moderna (Souza, 2018). Ao contrário da sociologia

3 É importante enfocar o trabalho pioneiro de Bolívar Lamounier (1985), em que o cientista político registra como o pensamento politico brasileiro era demarcado analiticamente pela falta e incompletude como comparado aos países centrais. Assim, teríamos uma irremediável particularidade nacional: "Seria ingênuo supor que a noção de 'adaptação' à realidade não se tenha transformado ao tornar-se moeda corrente no vocabulário político brasileiro" (Lamounier, 1977, p. 394). 
da inautenticidade, Souza defende que temos sociedades do mesmo tipo, ou seja, a modernidade possui um caráter contraditório na periferia e no centro, que poderia ser visto através da reprodução simbólica do capitalismo. Com a teorização do sociólogo, teríamos motivos estritamente modernos para a exclusão social. Nesse sentido, Souza possui grande relevância entre nossas tradicionais interpretações, pois as mais importantes leituras têm no atraso, como vimos, o elemento decisivo a explicar os dilemas brasileiros ${ }^{4}$.

Lynch (2013) afirma que nossos intelectuais têm como característica fundamental considerar suas produções como inferiores àquelas formuladas na Europa e nos Estados Unidos, que são nossas referências de teoria. Assim, não encontramos possibilidade de produzir teoria, tendo como única alternativa aplicar aquelas dos países cêntricos (Lynch, 2013). Com sua teorização, Jessé Souza traz uma importantíssima contribuição para fugirmos do fantasma da condição periférica, que faz com que nos representemos permanentemente como inferiores e incapazes de teorizar (Lynch, 2013).

No entanto, Sérgio Tavolaro (2005) defende que Souza, mesmo fazendo uma crítica forte à sociologia da inautenticidade, termina ficando à sombra desta mesma sociologia porque sua teorização em torno da modernização seletiva reproduz uma perspectiva singular de modernidade, que contem a imagem de desvio inequívoco do Brasil em relação aos países centrais (Tavolaro, 2005).

Apesar de concordar com a tese de que Souza fica à sombra da sociologia da inautenticidade, vou construir minha interpretação em sentido diferente daquele defendido por Tavolaro. Isso porque

4 Werneck Vianna (2004b) argumenta sobre as interpretações do Brasil produzidas na década de 1970, quando foram formuladas grandes ensaios sobre o país: "A situação de transparência a que o regime militar expôs a outrora enigmática antinomia atraso-moderno implicava para a ciência social um novo desafio, qual seja, o de formular a natureza particular do processo de modernização conservadora no Brasil. A produção dos anos 70 investe nessa direção, retomando a grande-angular do ensaísmo das antigas elites intelectuais e da Sociologia macroestrutural da década de 1950" (p. 223). E demonstra também como a construção de uma grande interpretação do Brasil deixa de ser elemento central: "O fato é que essa bibliografia encerra a controvérsia sobre a polaridade atraso-moderno, elegendo a década seguinte outros temas e outros problemas, transitando-se do state-building à cidadania - como anunciava o influente Cidadania e justiça, publicado em 1979, de Wanderley Guilherme dos Santos, sinalizando o que vai ser o momento de retorno da Sociologia como disciplina da reforma social." (p. 224). 
acredito que a ligação de Souza com os autores clássicos por ele criticados não ocorre apenas pela reiteração da imagem de desvio da realidade brasileira quando comparada aos países centrais, mas pela reprodução das interpretações sobre o Brasil agrário e escravista que estes construíram e que são repetidas acriticamente pelo sociólogo.

Precisamente, defendo que Souza repete o dualismo rural-urbano que é crucial para o autor permanecer à sombra da sociologia da inautenticidade e continuar reproduzindo, assim, a imagem do Brasil como incompletude, desvio e falta quando comparado aos países centrais, e que Tavolaro demarca tão bem. Mesmo trazendo uma concepção inovadora das ações de mercado e Estado quando comparada às interpretações do pensamento social e político brasileiro, defendo que a permanência do dualismo na teorização de Souza faz com que suas teses sobre a modernização seletiva e a ralé estrutural fiquem organizadas sobre bases frágeis. Isto ocorre porque as ações de mercado e Estado estão limitadas ao âmbito urbano, o que resulta na reiteração da imagem do Brasil agrário e escravista presente nas interpretações clássicas criticadas pelo sociólogo. Como consequência das ações limitadas das duas principais instituições do mundo moderno, sustento que Souza se aproxima das interpretações que, em princípio, estariam completamente afastadas de sua teorização.

Problematizo a ruptura de Souza com a sociologia da inautenticidade a partir da exposição do clássico Raízes do Brasil, uma vez que o sociólogo considera Sérgio Buarque de Holanda como o fundador das ciências sociais conservadoras no país. Minha leitura, todavia, é construída em sentido contrário àquele produzido por Leal e Matos (2016), que criticam a obra de Souza para exaltar a interpretação culturalista de Holanda. Também se difere da crítica feita por Ruy Braga (2017), que, apesar de observar consequências políticas importantes para a constituição de uma ação coletiva transformadora da ralé estrutural, prefere concentrar seu esforço na crítica à leitura de Souza da teoria do populismo de Francisco Weffort (2003). Meu objetivo é problematizar a ruptura de Souza 
com a sociologia da inautenticidade, mas deixando bem demarcados os avanços e limites presentes em sua teorização ${ }^{5}$.

Para alcançar meus objetivos, divido o artigo em cinco partes. Na primeira, faço uma leitura contextual de Raízes do Brasil que inexiste na interpretação de Souza. Conjuntamente, demonstro o peso central que o dualismo possui na sociologia brasileira. $\mathrm{Na}$ segunda parte apresento as críticas de Souza à sociologia da inautenticidade e Holanda, em particular. Na terceira, exponho as suas teses sobre a modernização seletiva e a subcidadania. Na quarta, apresento a leitura de Souza das obras de Florestan Fernandes e Maria Sylvia de Carvalho Franco, que possuem importância central para o autor.

Por fim, exponho uma leitura de Franco diferente da realizada por Souza, para sustentar que o sociólogo reproduz de forma acrítica as leituras clássicas sobre o Brasil rural e escravista. Conjuntamente, exponho a interpretação de Cardoso (2008, 2010), que me auxilia a sustentar empiricamente as críticas às teses de Souza sobre a singularidade da modernidade brasileira e da desigualdade social.

\section{Raízes do Brasil e suas edições}

Como primeiro caminho para problematizar a ruptura de Jessé Souza com a sociologia da inautenticidade, exponho a interpretação de Holanda em Raízes do Brasil, levando em consideração o contexto no qual estava inserida e enfatizando a relação dual entre rural (tradicional) e urbano (moderno). Acredito que o enfoque contextualizado proporciona condições para sustentar meu argumento. Antes, porém, é necessário demonstrar que essa relação de contraposição entre as duas esferas não foi algo sempre presente na obra de Holanda, como a interpretação descontextualizada de Souza deixa transparecer.

5 No sentido proposto acima irei, evidentemente, trilhar um caminho contrário às interpretações que naturalizam a crítica de Jessé Souza à sociologia da inautenticidade, como é o caso do trabalho de Delgado (2017), que tece elogios e repete as críticas de Souza aos autores por ele analisados. Como disse acima, reconheço méritos na empreitada teórica de Jessé Souza. No entanto, também existem problemas importantes que necessitam ser tematizados e criticados, que não diminuem as contribuições trazidas pelo sociólogo. 
Feldman (2013) realiza uma análise diacrônica das três primeiras edições de Raízes do Brasil, publicadas em 1936, 1948 e 1956, para defender que as afirmações que são feitas sobre a obra clássica de Holanda só possuem exatidão quando uma das edições é alçada como elemento de referência. Este é um ponto muito importante, pois além de trazer uma leitura descontextualizada de Raízes do Brasil, Souza ainda apresenta as teses da versão definitiva como se elas sempre tivessem a mesma formatação.

De acordo com Feldman (2013, p. 120), existem três mudanças centrais que justificam a análise cuidadosa a partir da edição escolhida, que são as seguintes questões: (i) a variação de sua postura axiológica acerca da tradição; (ii) a substituição do personalismo pela democracia como saída política para a nascente ordem urbana; e (iii) a reformulação do enunciado do desterro com condição característica do brasileiro. Vou focar na questão da tradição, pois é elemento central para a leitura de Souza da obra de Holanda.

$\mathrm{Na}$ edição de 1936, Holanda avalia que as perspectivas de modernização da sociedade brasileira deveriam ser avaliadas com reticências, uma vez que a força da cultura do personalismo, da ética da aventura, do ruralismo e da cordialidade recomendava esse tipo de comportamento (2013, p. 121). Nesse momento, o americanismo era visto como alternativa problemática ao iberismo, pois havia a indicação da conciliação entre tradicional e moderno (Feldman, 2013). Na edição de 1948, por sua vez, a clivagem entre tradição e modernização se coloca como uma relação de profunda incompatibilidade:

Tal como reconstruída até aqui, a disjunção entre a argumentação das edições de 1936 e de 1948 envolve, naquela, a reticência frente às perspectivas de implante da modernização (para a qual seria necessária, no mínimo, uma composição com as estruturas existentes) e, nesta, a necessidade de algum tipo de ruptura com o tradicional para a implantação do moderno (Feldman, 2013, p.123). 
Outro elemento central que precisa ser enfatizado é a caracterização do homem cordial. Na primeira edição do livro, o homem cordial representava a contribuição brasileira à humanidade e, consequentemente, formaria o caráter nacional, pois a cordialidade teria um modo incontornável (Feldman, 2013, p.123). Nessa edição, portanto, o autor constrói o homem cordial como uma categoria abrangente que caracterizaria o brasileiro de maneira geral, pois seria a contribuição nacional ao mundo (Feldman, 2013). Todavia, nas edições de 1948 e 1956, Holanda se afasta da relação entre cordialidade e caráter nacional presente na edição de 1936. A partir das edições posteriores, a antítese cordialidade-civilidade é intensificada, mesmo constituindo uma dialética sem síntese (Feldman, 2013, p.124). Assim, é um equívoco afirmar que o homem cordial se apresenta como uma categoria abrangente para caracterizar o brasileiro na edição definitiva de Raízes do Brasil.

Outra questão central é a caracterização do personalismo feita pelo autor. Ao apontar as transformações ocorridas no Brasil a partir do final do século XIX, Holanda afirmava na edição de 1936 que as modificações políticas em termos de implantação da democracia eram infrutíferas, uma vez que o personalismo funcionava como elemento estabilizador, ou seja, o equilíbrio político apenas poderia ser alcançado por seu intermédio (Feldman, 2013, p.128). Nessa edição, portanto, Holanda reproduz uma perspectiva conservadora próxima de Gilberto Freyre, este último considerado um natural antípoda de Holanda por Souza (2016). De acordo com Feldman (2013) "Sobressai no texto da segunda edição a crítica à classe dominante e ao esvaziamento do programa democrático pelo tradicionalismo, ausentes na versão original (p. 126)". A partir das diferenças existentes nas edições de Raízes do Brasil, Feldman (2013) demonstra como a obra do autor se tornou um dos pilares da interpretação progressista sobre o Brasil. Essa posição só foi possível porque o autor modificou sua resignação pragmática com a cordialidade na edição de 1936, para uma aproximação cética com a civilidade nas edições de 1948 e 1956 (Feldman, 2013, p.137). 
Além de apontar as modificações nas edições de Raízes do Brasil, é importante assinalar também que as teses contidas no livro não constituem a interpretação definitiva do autor sobre o Brasil, como a leitura generalista e descontextualizada de Jessé Souza deixa transparecer. Wegner (1999) analisa os trabalhos de Holanda sobre o bandeirantismo e monções para defender que, nessas obras que tratam sobre a conquista do Oeste brasileiro, Holanda deixa de lado a interpretação genética presente em Raízes do Brasil para a construção de uma explicação situacional, "incorporando no argumento um 'americanismo' no sentido da dinâmica própria ao Novo Continente, o que leva a uma modulação da relação entre tradição e modernidade em sua obra" (Wegner, 1999, p. 241). Com essa perspectiva, Holanda estaria preocupado em apontar, por exemplo, os elementos em comum para construir uma análise comparativa com os Estados Unidos, e não a reprodução de uma comparação em termos absolutos como existente em Raízes do Brasil. A fronteira seria o caminho para analisar o processo de americanização em sentido continental. No seu livro Monções, publicado em 1945, que trata do comércio fluvial entre o planalto paulista e Cuiabá, Holanda não utiliza generalizações como cordialidade e civilidade presentes em Raízes do Brasil (Wegner, 2009, p. 219). A partir dessa perspectiva, Holanda constrói uma nova relação entre tradição ibérica e modernização em suas obras dos anos 1940:

Aplicando, para esse momento da obra de Holanda (no qual as grandes caracterizações e o recurso a tipos ideais são evitados), os termos utilizados em Raízes do Brasil, poderíamos dizer que agora a cordialidade lentamente se disciplina e se civiliza, sem contudo romper radicalmente com suas características iniciais. Dessa maneira, estamos diante de uma situação em que a nossa tradição se moderniza 'por dentro', não ocorrendo, como antes, uma absoluta incompatibilidade entre modernização e tradição, e sim uma possível convergência destes com os influxos externos de modernização (Wegner, 1999, p.254). 
Como visto na citação acima, Raízes do Brasil não representou a única intepretação de Holanda sobre a relação entre tradição e modernidade. Como a interpretação de Souza sobre Holanda é marcada pela ausência de contextualização e por uma generalização abusiva, é importante contextualizar as publicações para demonstrar que a crítica de sociólogo recai sobre as apropriações que são feitas da obra de Holanda, e não sobre os argumentos do autor em si. Abaixo, exponho a interpretação de Holanda na versão definitiva de Raízes do Brasil para enfocar como o autor trabalha a dicotomia rural (tradicional) - urbano (moderno).

Wegner (1999) argumenta que Raízes do Brasil teve como ponto central analisar os dilemas da modernização brasileira, através de uma perspectiva genética das raízes do tradicionalismo. A partir da versão definitiva da obra temos a relação de contraposição entre cordialidade e democracia, tradição e modernidade (Wegner, 2009, 1999). Ocorre a relação contrastante entre racionalidade e abstração representando a modernidade existente no âmbito urbano, contraposta à cordialidade produzida pelo mundo rural. Mesmo sem um projeto político, Raízes do Brasil tem uma aposta no processo de modernização como caminho para vencer o atraso representado pelos valores da cordialidade construídos no Brasil rural.

Holanda (2010) defende que recebemos como herança ibérica a cultura personalista que possuía como traços característicos a acentuação do irracional, do afetivo e do consequente tradicionalismo. Essa herança, por sua vez, dependia essencialmente das instituições agrárias (Candido, 2010). O Brasil colonial e rural teve o domínio do tradicional em detrimento da atrofia das qualidades modernas, impessoais e ordenadoras que seriam marcas do âmbito urbano (Holanda, 2010). Como exemplo, Holanda cita a organização interna da família patriarcal, que tinha no personalismo e no afeto seus elementos essenciais. Assim, uma organização a partir de interesses impessoais ou ideias racionais seria algo absolutamente estranho àquela realidade.

Devido à força que possuía como fator estruturante de todas as relações sociais, econômicas e políticas existentes no período 
colonial, essa estrutura agrária, personalista e tradicionalista terminou sendo transplantada depois do processo de independência (Holanda, 2010).

A vinda da família real é vista por Holanda como a primeira ação de ameaça aos valores rurais, uma vez que trazia consigo a cultura cosmopolita construída em âmbito urbano. O Brasil imperial recebeu como herança a estrutura agrária, patriarcal, escravista e de razão essencialmente diversa do capitalismo que, por sua vez, seria expressão de uma cultura burguesa e urbana. Essa herança foi possível devido à força da escravidão. Dentro dessa lógica, o homem cordial seria um representante típico do Brasil agrário, patriarcal e tradicional, que teria nos sentimentos, e não nos interesses racionais e impessoais, o elemento definidor da ação social. Assim, o Brasil rural, personalista e tradicional terminou sendo o elemento vencedor. Holanda (2010) defende que o fim da escravidão, em 1888, representou o término do predomínio agrário e o início da lenta revolução brasileira no sentido da construção de um país no qual os valores urbanos, racionais, impessoais e modernos fossem os pilares centrais.

Além de apontar como o dualismo está presente em Raízes do Brasil, é importante demonstrar como esse elemento é central no pensamento social e político brasileiro, sobretudo nas sociologias modernistas existentes entre as décadas de 1930 e 1950, como veremos a seguir.

Martins (2014) analisa a sociologia modernista produzida nos anos 1930, que tinha como ponto central a crítica à ausência de universalidade nas relações entre Estado e sociedade, porque apontava os empecilhos para a construção da vida pública no Brasil (Martins, 2014, p. 584). As características agrárias eram interpretadas por essa sociologia como tradicionalismo e, consequentemente, como grande empecilho para a institucionalização da modernidade ocidental no país (Martins, 2014). Para a sociologia modernista, o grande dilema brasileiro para a construção da modernidade estava na estrutura colonial e agrária, sobretudo no que se refere a dimensões como a separação entre público e privado, 
a diferenciação social, a racionalização e a secularização, pois não conseguimos instituir um desenvolvimento similar ao existente nos países centrais (Martins, 2014).

Muito além de construir uma visão a-histórica do brasileiro, a sociologia modernista tinha como objetivo usar suas produções para vencer a dicotomia rural-urbano que se tornava nosso maior dilema (Martins, 2014). Não por acaso, os anos 1930 tiveram como uma das marcas fundamentais a combinação entre cultura e política, como demonstrada pela atuação da sociologia: "o modernismo, ao pensar um código moral civilizatório distinto e animado pela construção nacional ancorada em uma geografia original, permitia a afirmação do moderno através da modernização" (Martins, 2014, p. 594).

Villas Bôas (2006) aponta que as análises sobre a modernização que tinham como objetivo provocar a mudança social foram centrais no período entre 1945 e 1964, visto que essas interpretações analisam os impasses para a plena realização da sociedade moderna no Brasil (Cazes, 2014). Para essas interpretações seria necessária uma mudança provocada, capitaneada por eles no sentido da implantação de uma ordem plenamente moderna, estrutura pela sociedade de classes. Era fundamental, portanto, superar o passado atrasado (Cazes, 2014). Essa sociedade, por sua vez, teria como elemento intrínseco o ideal de competição justa, secularizada, democrática e subordinada a uma ordem burocrática, impessoal e legal (Villas Bôas, 2006, p. 61).

Segundo Villas Bôas (2014), a institucionalização da sociologia não representou a criação de novas questões ou hipóteses. Ela representou, no entanto, a reelaboração das questões anteriores através da demarcação da dualidade brasileira, dividida entre tradicional e moderna. Sobre a sociologia dos anos 1950, Villas Bôas (2014) argumenta:

A questão da modernidade se impõeà sociologia. O transplante de ideias, padrões científicos, hábitos e costumes "racionais" passam a constituir um dos focos polêmicos da atenção dos sociólogos. Embora discordassem quando à modalidade de 
integração do Brasil no conjunto das sociedades modernas, aceitavam esse desafio como exigência histórica, política e intelectual (p. 14).

A demarcação do objetivo central da sociologia brasileira entre as décadas de 1930 e 1950 é fundamental para eu sustentar que Souza não rompe com um traço central do pensamento social e político brasileiro, que é o dualismo entre rural e urbano ou tradição e modernidade, sobretudo se levarmos em consideração que o autor utiliza obras clássicas para reinterpretar o Brasil.

\section{Modernização seletiva e subcidadania}

Jessé Souza (1999) volta suas críticas às interpretações que partem da sociologia da dominação weberiana para conceituar o atraso brasileiro, que o sociólogo define como ideologia do atraso ${ }^{6}$. De acordo com Werneck Vianna (1999), o Weber recepcionado no Brasil não fora aquele das patologias da modernidade, mas sim do acesso ao moderno. Essas interpretações pressupõem a aceitação sem restrições do diagnóstico weberiano sobre o desenvolvimento ocidental (Souza, 1999). Como consequência, o que é tradicional e moderno fica implícito nas análises como referência absoluta (Souza, 1999, p. 17). Desta forma, a denominação ideologia do atraso é justificada porque somos comparados aos Estados Unidos, que seriam essencialmente um país moderno, protestante e democrático, marcado pelo controle de afetos e pela disciplina impessoal, pois foi onde o racionalismo ocidental teria se desenvolvido de

6 Neste artigo estou utilizando também as obras atuais de Jessé Souza, como a Tolice da inteligência brasileira (2015), A radiografia do golpe (2016) e A elite do atraso: da escravidão à Lava Jato (2017), para reforçar os argumentos sobre a sociologia da inautenticidade formulados originalmente em A modernização seletiva: uma reinterpretação do dilema brasileiro (2000) e A construção social da subcidadania: para uma sociologia política da modernidade periférica (2006a). Os argumentos novos apresentados por essas obras, sobretudo referentes às classes sociais e à conjuntura política iniciada com as Jornadas de Junho foram abordados em outro lugar (Ribeiro, 2017). 
forma plena ${ }^{7}$ (Souza,1999). Se os Estados Unidos tiveram a herança moderna do protestante ascético, o Brasil, por sua vez, é caracterizado pela pré-modernidade, representado pelo catolicismo e pelas relações pessoais e afetivas (Souza, 1999). Souza (1999) afirma que um princípio absoluto para construção de comparações culturais não serve à ciência, mas apenas à ideologia. Isso porque as interpretações culturalistas que demarcam o atraso brasileiro constroem formulações baseadas na indeterminação, não favorecendo a um conhecimento preciso do que teríamos de efetivamente atrasado em relação aos Estados Unidos (1999). A maneira como são construídas essas interpretações nos deixa em posição de permanente subalternidade.

Holanda (2010) possui importância central para a construção da visão hegemônica sobre o Brasil contemporâneo, pois seria o grande sistematizador das ciências sociais no século XX através da junção das teses do personalismo e do patrimonialismo, conceitos que demonstrariam como a sociedade brasileira enfatizaria os laços pessoais como unidade moral organizadora das relações sociais (Souza, 2006b).

Raízes do Brasil teria produzido a interpretação dominante do mito nacional através da tese do homem cordial (Souza, 2016). Holanda seria responsável por incorporar acriticamente o racismo científico, uma vez que nos interpreta como possuidores de uma tendência inata à corrupção (Souza, 2016, p. 35). O homem cordial seria a representação do brasileiro genérico de todas as classes, emotivo, indigno de confiança, presos às paixões do corpo e tendencialmente corrupto (Souza, 2015, p. 49).

Com a obra de Holanda, a corrupção tornou-se um dilema interpretado como exclusivamente brasileiro (Souza, 2016). Desta forma, o homem cordial nada mais é do que a incorporação da dominação e a consequente reprodução do sentimento permanente de

7 É importante frisar que Jessé Souza não é o primeiro a interpelar criticamente as interpretações de base culturalista que nos comparam aos Estados Unidos para caracterizar o atraso brasileiro. Werneck Vianna (2004a) faz uma importante análise dos diagnósticos e projetos políticos apresentados pelos americanistas, além de contrapô-las às intepretações iberistas que, por sua vez, valorizam a herança cultural deixada pela colonização portuguesa. 
inferioridade (Souza, 2016). A interpretação de Raízes do Brasil foi fundamental para a construção, portanto, de uma separação ontológica entre os países do Atlântico Norte e o Brasil (Souza, 2015).

Em caminho contrário à argumentação de Souza, é importante apontar que o sentido definitivo da noção de homem cordial não tinha como objetivo fazer uma caracterização geral do brasileiro, mas sim uma crítica ao Brasil agrário e seus representantes. A caracterização geral do brasileiro, como vimos, é realizada apenas na edição de 1936. Assim, reitero que as críticas de Souza recaem sobre a apropriação das teses de Holanda e não sobre os argumentos do autor em si, como demonstra o trecho a seguir:

Uma ideologia melhor para os interesses da elite econômica não existe. A leitura de Sérgio Buarque foi ensinada nas escolas e nas universidades de todo país - como acontece até hoje - e tornou possível fazer de mote da corrupção apenas do Estado o núcleo de uma concepção de mundo que permite a elite mais mesquinha fazer todo um povo de tolo (Souza, 2017, p. 33).

Mata (2018) traz uma questão interessante sobre Souza e a sociologia da inautenticidade, porque o sociólogo construiu uma relação contraditória entre a defesa da modernidade periférica e o atraso de nossa sociologia. Precisamente, a sociedade brasileira moderna teria uma sociologia presa em um estágio pré-sociológico. Assim, teríamos uma sociologia do atraso da sociologia com Jessé Souza (Mata, 2018, p. 429). Mesmo com a demarcação de uma questão relevante, Mata (2018) critica Souza sem aproximá-lo analiticamente da sociologia da inautenticidade, o que acredito ser o elemento mais consistente para a crítica às suas teses.

Nesse primeiro momento de embate com as interpretações culturalistas do Brasil, Souza demonstra seus pressupostos e defende a necessidade de construirmos comparações empiricamente fundadas para saber o que realmente temos de atrasados em relação aos Estados Unidos, por exemplo. Certamente, é um dos pontos altos de sua teorização. 
Depois de criticar a visão hegemônica sobre o Brasil, Souza (2006a) procura levar a cabo seu paradigma alternativo, definido como a construção de uma teoria crítica da modernização periférica. Em A Modernização Seletiva (2000), Souza propõe um diálogo crítico com a sociologia da inautenticidade, que recepcionou o Weber do atraso, para a construção de outra leitura do sociólogo alemão para pensar o processo de modernização do país e nossos principais dilemas. Essa releitura foi realizada a partir do Weber do racionalismo ocidental e das patologias da modernidade ${ }^{8}$. Além da proposição de uma nova leitura da sociologia weberiana, Souza parte de um diálogo com as duas principais obras de Gilberto Freyre, Casa-Grande \& Senzala e Sobrados e Mucambos.

Souza (2006a) inicia sua reinterpretação através da obra Casa-Grande \& Senzala. O sociólogo segue Freyre (2005) ao defender que durante o período colonial o Estado mostrou-se uma realidade ausente, uma vez que o patriarcalismo teria funcionado como fator estruturante não apenas da sociabilidade existente, mas também das relações políticas e econômicas. A sociedade colonial giraria em torno do patriarca, uma vez que a família seria o alfa e ômega da organização social da colônia (Souza, 2006a, p. 104). Não existiam limites à autoridade do patriarca, pois a ausência de limitações externas fazia com que as inclinações emotivas do patriarca fossem decisivas para as relações sociais (Souza, 2017, p. 53-4). O patriarca, portanto, era o bárbaro que não conhecia nenhuma noção de limites para seus impulsos primários, pois eram sádicas as relações do senhor com as mulheres índias e negras, com as próprias mulheres

8 De acordo com Sell (2007), apesar de Souza partir da uma leitura neoevolucionista de obra de Weber, sua interpretação não se constitui como propriamente weberiana:"O ponto a destacar aqui é que Jessé de Souza não pôde lançar mão nem da literatura weberiana brasileira nem mesmo de elementos extraídos do próprio Weber para detectar, empiricamente, a especificidade da modernidade brasileira. Weber serve-Ihe para caracterizar a modernidade em si e, apenas nesta forma indireta, vincula-se à caracterização da 'modernidade brasileira'" (Sell, 2007, p. 246). Já Perlatto e Lima (2009), por sua vez, defendem que Habermas possui uma posição de centralidade na teorização de Jessé Souza sobre a modernidade periférica:"Uma interpretação sociológica densa da realidade periférica do Brasil, assim como a prática política consequente, requerem a compreensão de que, longe de estarmos aquém da modernidade, encontramo-nos, com efeito, embebidos na modernidade (e nas suas patologias). Eis a contribuição decisiva (mas não inédita, no panorama da nossa sociologia) que Jessé Souza, habermazianamente, nos lega" (Perlatto e Lima, 2009, p. 31). 
brancas, com os filhos e com os escravos (Souza, 2017, p. 52). Não havia, portanto, nenhuma possibilidade de ações de racionais de conteúdo impessoal na sociedade colonial. Teríamos sido fruto de uma sociedade singular estruturada pelo sadomasoquismo ${ }^{9}$, que demonstrava como o poder pessoal vigia de forma plena no Brasil colonial e tradicional:

É nesse contexto de total dependência dos escravos em relação ao senhor, sem a proteção que o costume e a tradição garantiam ao elemento dominado em outras sociedades tradicionais, possibilitando desse modo, em alguma medida pelo menos, formas de constituição de auto-estima e reconhecimento social independentes da vontade do senhor, é que podemos compreender a especificidade do tipo de sociedade, baseada no poder pessoal, que aqui se constituiu (Souza, 2006a, p. 121).

Souza (2006a) concede ênfase decisiva à escravidão, que ele analisa da mesma forma como fazem Freyre e Florestan. Para Souza, a escravidão, herança cultural moura, era um verdadeiro sistema social responsável por estruturar toda sociedade e também explicar a existência dos seus conflitos mais importantes: "Sendo uma espécie de 'instituição total' no Brasil, a forma peculiar da escravidão traria consigo a 'semente' da forma específica que assumiu o poder pessoal e familístico entre nós” (Souza, 2006a, p. 112).

9 Jessé Souza diverge da interpretação clássica de Gilberto Freyre formulada por Ricardo Benzaquen de Araújo (1994), por considerá-la a principal interpretação do sociólogo pernambucano:"Se a noção de'neolamarkiansmo'é fundamental para uma adequada compreensão da obra de Gilberto Freyre, o mesmo não se pode dizer da interpretação 'conteudista da obra como formulada por Araújo. O argumento do autor nesse ponto particular, ao enfatizar o elemento da contradição, que sem dúvida se refere a um ponto real e importante da reflexão freyriana, termina por se congelar na proposição de 'hybris', que por ser mero 'excesso', seja criativo ou destrutivo como afirma o autor, pode ser tudo e nada ao mesmo tempo, como a própria 'anarquia' vista por Araújo como a forma social da 'hybris'. A 'hybris' é feticizada e proposta como solução quando na realidade ela é um sintoma de um problema não resolvido, Ela acaba por se tornar uma pseudoexplicação" (p. 216-17). Além do trabalho de Benzaquen de Araújo, é importante fazer menção ao seminal trabalho de Elide Rugai Bastos, As Criaturas do Prometeu (2006) que, no momento da publicação de A Modernização Seletiva ainda não havia sido lançado. 
Souza (2006a), seguindo Freyre (2005), defende que o Brasil escravista e colonial era uma ordem singular e plenamente tradicional, fruto da herança cultural moura na forma de escravidão. A partir do tipo de escravidão que foi constituída no Brasil é que poderíamos compreender o peso decisivo da dominação pessoal de razão essencialmente diversa aos imperativos oriundos do sistema capitalista. A demarcação deste ponto é fundamental porque Souza continuará a interpretar o Brasil agrário durante o Império como uma ordem estruturada pela dominação pessoal tradicionalista e de sentido essencialmente distinto da ordem moderna, como veremos através de sua leitura distorcida da obra de Franco.

O domínio pleno do tradicionalismo durante o período colonial faz com que Souza (2000) interprete a modernidade chegando ao Brasil de maneira singular se comparada com a modernidade central, representada pela Europa e os Estados Unidos. As sociedades centrais tiveram uma herança religiosa forte e bem estruturada, a ponto de fazer com que as ideias fossem anteriores às práticas sociais, pois tiveram na ética religiosa um elemento central para que passassem por um processo de modernização de caráter transclassista. O Brasil, por sua vez, não possuiu essa herança religiosa de conteúdo moral e ético, fazendo com que a nossa esquematização da modernidade nos legasse as práticas sociais primeiro que as ideias. Desta forma, nos tornamos singularmente modernos, pois reproduzimos um processo de modernização seletiva ${ }^{10}$ e desviante em relação aos países centrais.

Como defendem Perlatto e Lima (2009), a tese sobre a instituição da modernidade brasileira fez com que a inautenticidade criticada por Souza aparecesse em sua própria teorização, uma vez que o sentimento de falta, incompletude e desvio em relação

10 Mesmo possuindo uma importante singularidade e um grau de seletividade, Souza (2000) defende que esta característica não é exclusiva do caso brasileiro:" Primeiro, esse exame de casos concretos nos permitirá demonstrar que a seletividade, ou seja, a realização parcial de aspectos do que usualmente associamos com a singularidade da cultura ocidental, é um atributo comum de todas as formas concretas de desenvolvimento observáveis no Ocidente" (p. 127). Para sustentar sua tese, Souza expõe os caos americano, alemão e brasileiro. 
à modernidade central permanece como uma dimensão fundamental da explicação ${ }^{11}$.

Precisamente, a modernização singular fez com que o elemento tradicional do período colonial fosse transplantado para o Império brasileiro. Ora, nesse sentido, a teorização de Souza não se difere das interpretações feitas pela sociologia da inautenticidade, a ponto de defender a existência de uma relação dual entre uma parte tradicional no campo e outra moderna, existente no meio urbano. Nesta questão, por exemplo, Souza segue a interpretação de Holanda, que critica com veemência como o intelectual responsável por produzir a interpretação mais conservadora sobre o Brasil contemporâneo.

A caracterização do período colonial como plenamente tradicional tem uma função estratégica no argumento de Souza (2000), que é defender a tese segundo a qual a modernidade central foi transplantada para o Brasil a partir de dois eventos históricos ocorridos no século XIX: a abertura dos portos e a chegada da Corte Portuguesa de Dom João VI, que fugia das tropas napoleônicas. Souza (2000) assimila a tese de Max Weber sobre o racionalismo ocidental para defender a transplantação da modernidade para o Brasil. Isto fez com que a abertura dos portos e a transplantação do Estado português significassem a entrada no Brasil de Estado e mercado como artefatos prontos. Esses eventos representariam o ponto zero da modernização brasileira (Souza, 2017).

A partir da transplantação destas instituições centrais da modernidade para a periferia, houve, segundo o autor, toda uma modificação nas relações de sociabilidade e na conduta dos indivíduos. Desta forma, as ações passaram a ser regidas pelas demandas oriundas das duas principais instituições do mundo moderno, responsáveis por reproduzir uma dominação impessoal, mesmo

\footnotetext{
11 Segundo Perlatto e Lima (2009): "A inautenticidade retorna, assim, por meio de uma apropriação weberianamente enviesada da habermasiana distinção entre sistemas e mundo-da-vida: o contexto religioso-valorativo específico da Europa ocidental na aurora da modernidade explicaria, assim, por negação, os casos heterodoxos de modernização. E com isso se explicaria porque o Brasil, importando práticas institucionais sem possuir o'lastro ideal e valorativo que lhe permita articulação, reflexividade e consciência de longo prazo dos dilemas e contradições'(Ibidem), constituiria esse monomento vivo de patologias da modernidade." (p. 9).
} 
que restrita ao âmbito urbano, pois foi instituída uma hierarquia das cidades baseada nas seguintes dualidades: "doutores/analfabetos, homens de boas maneiras/joões-ninguém. Competentes, incompetentes etc." (Souza, 2017, p. 72). A partir da ação seletiva de Estado e mercado, constituiu-se uma relação dual entre cidade e campo. As ações de Estado e mercado ocorreram de forma paulatina porque as instituições ainda não estavam constituídas em suas formatações maduras (Souza, 2006a).

Ao enfatizar a importância central de Estado e mercado, Souza não os analisa como realidades materiais ou neutras. Estas, por sua vez, reproduziriam uma hierarquia valorativa que produziria certo tipo de personalidade fundamental para o processo de reconhecimento social. Desta forma, aqueles que não se enquadrassem no tipo de personalidade requerida por estas instituições não seriam reconhecidos e, portanto, ficariam excluídos. Esta forma de concepção de Estado e mercado os coloca como fontes morais, pois estas instituições hierarquizariam o comportamento dos indivíduos (Souza, 2006a).

Devido à força moral de Estado e mercado, Souza defende que o processo de reeuropeização narrado por Freyre (2006) em Sobrados e Mucambos não era simplesmente um elemento superficial. Para o sociólogo pernambucano, apesar das modificações ocorridas no século XIX, o tradicionalismo continuava a ser o elemento decisivo.

Souza (2006a), por sua vez, defende que o processo narrado por Freyre teve como característica mais importante mudar a organização social brasileira de ponta à cabeça, pois o domínio pleno do tradicionalismo passou a ser duramente combatido pela força das instituições modernas transplantadas do centro. Com o processo de modernização em âmbito urbano, o poder tradicionalista do patriarca começava a ser questionado no Brasil do século XIX: "São esses novos valores burgueses e individualistas que irão se tornar o núcleo da ideia de modernidade e europeidade enquanto princípio ideologicamente hegemônico da sociedade brasileira a partir de então" (Souza, 2017, p. 63). Através de sua leitura alternativa da obra freyriana sobre o século XIX, Souza (2000) defende, portanto, 
que o Brasil começava a ser tornar um país singularmente moderno através da chegada de navio da modernidade europeia (Souza, 2017, p. 69). Mesmo em sentido diferente da sociologia da inautenticidade, o eurocentrismo também está presente na teorização de Souza.

A modernidade que paulatinamente se instituía no período imperial não fazia com que repetíssemos a história pregressa da Europa como apontamos acima, pois a esquematização de Estado e mercado fez com que constituíssemos uma modernidade singular. A Europa constituiu uma modernidade responsável por modernizar todas as classes. Através da generalização e homogeneização de um único tipo humano para todas as classes, foi possível criar condições para a universalização de uma efetiva e atuante ideia de cidadania (Souza, 2005, p. 67). Nossa singular esquematização, por sua vez, fez com que chegássemos à modernidade através de um caminho particular, que seria responsável por constituir seres humanos seletivamente modernizados e diferenciados.

A anterioridade das práticas em relação às ideias fez com que constituíssemos uma modernização seletiva, pois modernizamos apenas uma parte da sociedade que teve condições de responder às demandas modernas de Estado e mercado. A outra parte situada no campo, regida por uma lógica tradicional, acabou não sofrendo o processo de modernização e, com isso, terminou não reconhecida na ordem capitalista com o mesmo estatuto de cidadania. Construímos, portanto, um padrão específico de cidadania e subcidadania (Souza, 2006a). Para Souza (2017), a singularidade ocorria porque os valores individualistas e universalistas de Estado e mercado não foram generalizados para a base da sociedade, por isso o caráter seletivo e segmentado da modernidade entre nós (Souza, 2017, p. 59).

Em decorrência da seletividade do processo de modernização, a modificação da sociedade escravista para a sociedade de classes deixou como grande nódoa a constituição de uma nova hierarquia valorativa do capitalismo, estruturada por uma ordem competitiva pautada pela ideologia do mérito (Souza, 2006a). Essa mudança foi responsável por produzir uma massa de inadaptados 
às demandas de Estado e mercado, devido à modernização seletiva que os manteve tradicionais. Não houve a incorporação dos valores necessários para o reconhecimento social, porque os inadaptados não eram vistos como produtivos, disciplinados e socialmente úteis (Souza, 2005, p. 63).

Se nas sociedades centrais houve um processo histórico de aprendizado coletivo que resultou na homogeneização de uma economia emocional para todos os indivíduos, responsável por ser o fundamento do reconhecimento social infra e ultrajurídico e da moderna noção de cidadania (Souza, 2006a), esse processo ocorreu de forma seletiva e segmentada no Brasil. Em decorrência, não houve compartilhamento por todos da noção de dignidade do produtor útil, que é o elemento central para a disseminação da dimensão jurídica da cidadania e da igualdade garantida pela lei (Souza, 2006a, p. 116).

Tivemos o embate valorativo entre dois sistemas, ou seja, entre os europeizados e os não europeizados. Ou seja, entre aqueles que conseguiram incorporar uma economia moral moderna transplantada da Europa e aqueles que ficaram à margem do processo. Precisamente, a forma como a modernização foi esquematizada no Brasil fez com que reproduzíssemos uma ordem dual entre modernizados e tradicionais, que se transformariam no Brasil moderno em adaptados e não adaptados à sociedade capitalista (Souza, 2017). Houve a redefinição moderna do negro e do dependente formalmente livre (Souza, 2006a, p. 161), pois ficaram excluídos e formaram um grande contingente designado pelo autor como ralé estrutural. $\mathrm{O}$ estilo de vida capitalista possuiria um potencial civilizatório e emancipatório que não teria se institucionalizado plenamente na periferia, por conta dos obstáculos advindos de uma ordem rural e tradicional e do consequente processo de modernização seletiva. 
A partir do debate com Charles Taylor ${ }^{12}$ e Pierre Bourdieu ${ }^{13}$, Souza (2006a) reforça a visão de Estado e mercado como fontes morais, como já havia feito em sua leitura sobre Max Weber. Essas instituições hierarquizariam de forma opaca e invisível os indivíduos que se organizariam na sociedade capitalista de acordo com a sua ideologia espontânea da igualdade de oportunidades, seja no centro ou na periferia. Souza (2006a) defende que a ideologia que é reproduzida pela sociologia da inautenticidade como um fato concreto apenas existe como uma justificativa moral para a naturalização da desigualdade.

Para defender a singularidade da modernização e da cidadania brasileiras, Souza (2006a) constrói uma leitura alternativa do conceito de habitus de Bourdieu (2009). Se Bourdieu defende a existência de um único tipo de habitus, Souza advoga que a modernização seletiva foi responsável por gerar, como vimos, tipos humanos diferenciados, resultando em um padrão de (sub)cidadania típico da nova periferia ${ }^{14}$. Assim, Souza (2006a) defende a existência de uma pluralidade de habitus, cujo determinante de nossa desigualdade seria o habitus precário.

12 Sobre a importância de Charles Taylor, Jessé Souza (2006a) afirma: "Instituições como Estado e mercado, assim como as demais práticas sociais e culturais, já possuem implícita e inarticuladamente uma intepretação acerca do que é bom, do que é valorável perseguir, do valor diferencial dos seres humanos etc. A hermenêutica tayloriana tem como alvo principal precisamente tornasse pano de fundo implícito articulável e consciente" (p. 24).

13 As referências feitas a Charles Taylor e Pierre Bourdieu têm como objetivo apresentar os argumentos principais de Souza para que eu tenha condições de sustentar a ligação do autor com a sociologia da inautenticidade. Não tenho, portanto, intenção de expor as teorias dos autores ou avaliar como Souza as recepciona. Os autores foram fundamentais para a reconstrução da hierarquia moral subjacente ao mundo moderno (Souza, 2018). Este trabalho, certamente importante, fica como questão para um trabalho futuro. Outro ponto importante a ser demarcado é a relação direta e complementar entre A Modernização Seletiva e A Construção Social da Subcidadania: "Os dois livros são, assim, partes de um mesmo projeto que venho realizando desde a juventude: desconstruir a falsa teoria hegemônica sobre o Brasil, que "tira onda" de crítica social, baseada no que chamaria mais tarde de 'corrupção dos tolos' e que logrou se tornar uma espécie de 'segunda pele' dos brasileiros" (Souza, 2018, p.9-10).

14 Souza (2006a, p. 181) defende que o processo de modernização seletiva e a constituição de um padrão especifico de cidadania e subcidadania não se restringe ao caso brasileiro:"Estou convencido de que o mesmo vale para o que chamei de 'nova periferia', de modo a nomear um conjunto de sociedades, como as latino-americanas, por exemplo, resguardadas as peculiaridades históricas e regionais, que se constituem, como sociedades complexas, sob o impacto direto da expansão mundial da Europa". 
O habitus precário representou a reprodução de certo tipo de personalidade que terminou sendo julgada como improdutiva e disruptiva para a sociedade (Souza, 2005, p. 59). Isso ocorria porque esses indivíduos não tinham as precondições psicossoais para o reconhecimento na sociedade de classes, que são o habitus primário e a personalidade moderna (Souza, 2006a, p. 170). Como consequência, houve a produção de uma massa de inadaptados às demandas modernas e capitalistas de Estado e mercado na sociedade de classes, pois não conseguiram se modernizar de forma plena. Foi o habitus precário a causa última da inadaptação e da marginalização, pois representou a reprodução de uma massa de indivíduos inadequados para o trabalho produtivo no mercado capitalista competitivo (Souza, 2005, p. 64). Em virtude disso, a ralé estrutural não seria reconhecida como cidadã efetiva, sendo a desigualdade brasileira explicada pelo não reconhecimento social de cerca de um 1/3 de sua população: "O que singulariza nossa sociedade como um todo, a intuição inicial que guiou todos os meus trabalhos, é, portanto, a subclasse dos subhumanos" (Souza, 2017, p.153). A partir da teorização de Souza, o Brasil teria uma forma moderna de exclusão social, que servia para desautorizar as interpretações culturalistas e essencialistas do atraso brasileiro:

Nesse sentido, meu argumento implica que nossa desigualdade e sua naturalização na vida cotidiana é moderna, posto que vinculada a eficácia de valores e instituições modernas com base em um bem-sucedida importação de "fora para dentro"(Souza, 2006a, p.17).

Nesse sentido, Souza afirma que as interpretações que focam o dilema da desigualdade como fruto de fatores pré-modernos, como o patrimonialismo, repetem uma visão do mundo como se este fosse transparente. Para o sociólogo, todavia, a sociedade moderna produz consensos opacos e inarticulados responsáveis pelo esquecimento da ralé estrutural e pela consequente naturalização da desigualdade: "Ora, é precisamente o abandono secular do negro e 
do dependente de qualquer cor à própria sorte, a 'causa' óbvia de sua inadaptação" (Souza, 2005, p. 66).

Em contraste com a modernidade periférica, que produziu uma dualidade intrínseca entre adaptados e inadaptados, ou seja, entre cidadãos e subcidadãos, a modernidade central teve como elemento decisivo, na passagem da sociedade tradicional para a moderna, a generalização do tipo único de personalidade burguesa, responsável por generalizar atributos como o domínio da razão sobre as emoções, cálculo prospectivo e auto responsabilidade às classes dominadas (Souza, 2006a, p. 165). As sociedades centrais, portanto, tiveram como consequência um amplo processo de aprendizado moral e político que inexistiu na modernidade periférica.

Até o governo Vargas seríamos regidos ainda por uma ordem dual, ou seja, tendencialmente moderna nas cidades e tradicional no campo (Souza, 2006a, p. 183). Com a revolução de 1930, tivemos “a entronização da lógica da dominação material e simbólica tipicamente impessoal e opaca do capitalismo, também na periferia, que engloba e redimensiona, segundo sua própria lógica, todas as relações sociais" (Souza, 2006a, p. 182). A partir desse momento, houve a intensificação da exclusão de $1 / 3$ da população brasileira com a modernização em grande escala.

Como resultado da modernização singular, constituímos, como vimos, uma dualidade entre setores europeizados (modernizados) e setores não europeizados (tradicionais), ou seja, entre aqueles que conseguiram se adaptar às demandas modernas de Estado e mercado e aqueles que, devido à inadaptação, terminaram formando a ralé estrutural:

Com a designação "europeu” eu não estou me referindo, obviamente, à entidade concreta "Europa", nem muito menos a um fenótipo ou tipo físico, mas ao lugar e a fonte histórica da concepção culturalmente determinada de ser humano que vai ser cristalizada na ação empírica de instituições como mercado competitivo e Estado racional centralizado, as quais, a partir da Europa, literalmente "dominam o mundo" em todos os seus 
rincões e cantos, como exemplarmente mostra o caso brasileiro em detalhe que já examinamos (Souza, 2006a, p. 281).

A teorização de Jessé Souza sobre a subcidadania faz com que a ralé estrutural não tenha condições de superar sua situação de classe, ou seja, havia uma incapacidade congênita para os excluídos alcançarem o reconhecimento social para que pudessem romper com o círculo de ferro no qual elas estavam enredados. Precisamente, não havia condições para uma ação coletiva transformadora da ralé estrutural. Mesmo partindo de um ponto de vista distinto, a incapacidade transformativa das classes populares presente na sociologia da inautenticidade também é repetido pela sofisticada teorização de Souza. Ademais, apesar de negar o culturalismo e as interpretações que demarcam o tradicionalismo como nosso principal dilema, Souza também reproduz uma perspectiva culturalista para compreender a inexistência de reconhecimento da ralé estrutural. Isto porque Estado e mercado são vistos como fontes morais, ou seja, valorativas. É a não incorporação dos valores da sociedade capitalista moderna que explicaria a desigualdade social: "A teoria crítica da estratificação social trilha, a seu modo, a mesma viagem redonda de que falava Raymundo Faoro, e o ponto de fuga da crítica ao culturalismo é algo como um culturalismo de segunda ordem" (Mata, 2017, p. 434).

Minha hipótese é que as teses sobre a modernização seletiva e a subcidadania terminam não conseguindo se desvencilhar totalmente das interpretações que são utilizadas de forma instrumental pelo autor, como são os casos de Freyre e Florestan, e àquelas que ele critica como é o caso de Holanda. Precisamente, as teses principais de Souza ficam muito próximas das interpretações dos autores acima citados, porque a teorização sobre a modernização seletiva e a subcidadania é tributária da dualidade rural-urbano. Assim, vale o questionamento se, de fato, temos como marca distintiva uma modernização seletiva e uma ralé estrutural nos moldes construídos pelo autor. 


\section{Para além da sociologia da inautenticidade?}

Passo a analisar a interpretação que Souza realiza dos trabalhos de Franco e Florestan, que são utilizados para corroborar suas teses sobre a modernização seletiva e a subcidadania. $O$ trabalho de Franco daria a possibilidade de Souza demonstrar como o tradicionalismo do negro, que terminou fazendo com que ele não se adaptasse às demandas capitalistas, modernas e impessoais da ordem competitiva, também fosse elemento presente no homem livre pobre de qualquer cor, uma vez que o personalismo possuiria um lugar estrutural em todas as relações sociais do sistema escravista (Souza, 2006a).

Através da obra de Franco, Souza demonstraria, portanto, como o tradicionalismo presente no comportamento dos escravos era elemento estruturante do Brasil agrário e escravista. Esse domínio estrutural do tradicionalismo ocorreria porque o dependente formalmente livre seria um subproduto deste sistema responsável por embasar todas as relações sociais (Souza, 2006a). Através do trabalho de Franco, seria possível sustentar a existência de um padrão de subcidadania típico do Brasil e da nova periferia.

De acordo com Souza (2006a), o trabalho de Franco lhe interessara porque oferecia uma investigação empírica do drama psicossocial do dependente formalmente livre, que possibilitava a generalização da pesquisa da autora sobre Guaratinguetá, no Vale do Paraíba, ao restante do Brasil. Esta região do Estado de São Paulo tinha como uma marca crucial a pobreza. Souza (2006a) aponta corretamente como a análise de Franco era generalizável a outras regiões do país, mesmo que em sentido oposto àquele defendido pela autora.

Souza (2006) enfatiza a dimensão prático-moral para apontar como a violência era um fator estruturante das relações sociais e, consequentemente, para a ausência de um código moral que impusesse padrões institucionalizados de conduta como havia ocorrido no centro. Em virtude disso, instituímos uma ordem desviante em relação àquela realidade, pois nos formamos de maneira inferior em termos materiais e simbólicos: "Aqui notamos a mesma ausência da institucionalização de uma esfera moral autônoma de fundo 
ético-religioso, que caracteriza a nova periferia, que também havíamos notado em Casa Grande e Senzala” (Souza, 2006a, p. 12).

Devido ao déficit ético-religioso, tivemos no Brasil escravista o personalismo e a honra como elementos decisivos das relações sociais. Souza (2006a) utiliza o trabalho de Franco para corroborar seu argumento sobre o peso da escravidão como instituição total, mas que é negado pela autora.

O sociólogo defende que a imposição da violência como elemento estruturante das relações sociais não era apenas reflexo da pobreza material e da escassez que explicariam o horizonte moral do dependente, mas de sua pobreza espiritual, moral e simbólica, que transformava a violência no único código legítimo (Souza, 2006a, p. 124). A violência, portanto, representava o tradicionalismo do sistema escravista interpretado como instituição total:

No entanto, o que existe aos meus olhos de mais interessante e importante no trabalho de Carvalho Franco é o magistral desvelamento do código de honra que unia, numa relação vertical cujo vínculo hierárquico era tomado naturalizado e intransparente, dependente e senhor de terras. É esse vínculo hierárquico naturalizado e tornado intransparente que esclarece a importância do escravo como "presença ausente" conferindo, apesar de não ser um ele direto da referida relação, o seu caráter peculiar. Como vimos, era o escravo que ocupava o lugar produtivo fundamental no sistema escravocrata. Vimos também que o dependente livre era, por conta disto, obrigado a ocupar as franjas e os interstícios da atividade econômica principal. Isso o obrigava a uma dependência objetiva em relação ao senhor de terras, apesar da ilusão subjetiva de liberdade ser um componente construtivo dessa forma peculiar de dominação pessoal (Souza, 2006a, p. 124-5).

Para Souza (2006a), o elemento mais importante do trabalho de Franco é a revelação da força e das vicissitudes da dominação pessoal de razão essencialmente diferente dos valores do sistema capitalista. 
Ao enfocar as relações de favor do agregado com o senhor, Souza (2006a) afirma que a peculiaridade da dominação pessoal brasileira está na ausência de um código moral explícito e compartilhado por todos, fato não ocorrido no centro que teve a religiosidade ética como elemento estruturante para constituição da sociedade moderna, racional, secular e regida por uma lógica impessoal:

O primeiro aspecto relevado por Carvalho Franco é o fechamento de horizonte de possibilidades dessa população para a compreensão de qualquer relação impessoal. Todo horizonte de significados, no contexto examinado, é sempre redutível a motivos e atributos de sujeitos concretos. Não existe a possibilidade de "abstração valorativa" que pudesse permitir pensar-se em termos de valores universalistas ou impessoais (Souza, 2006a, p. 126).

A relação de contraprestação de favores e proteção apontava para um quadro de sujeição absoluta à boa vontade do senhor, ou seja, demonstrava o domínio inconteste da dominação pessoal e do tradicionalismo no Brasil rural e escravista, assim como está presente nas obras de Holanda e, sobretudo, Freyre, com a qual o trabalho de Franco guardaria várias similitudes. $\mathrm{O}$ elemento estruturante dessa sociedade, portanto, é a dominação pessoal e tradicionalista.

Escravos e homens livres possuíam o mesmo caráter de submissão pessoal aos desejos do senhor (Souza, 2006a). Para tanto, Souza (2006a) defende a existência de uma contiguidade entre a pesquisa de Freyre sobre a escravidão muçulmana e a realizada por Franco sobre o dependente formalmente livre, pois elas demonstrariam a inexistência de tomada de consciência racional dos seus interesses:

Ambos irão formar a "ralé" dos imprestáveis e inadaptados ao novo sistema impessoal que chega de fora para dentro "como prática institucional" pura, sem o arcabouço ideal que, nas sociedades centrais, foi o estímulo último para o gigantesco processo de homogeneização do tipo humano contingente e 
improvável que serve de base à economia emocional burguesa, e que permite a sua generalização também para as classes subalternas. É apenas quando este processo é levado a cabo com alguma medida significativa de sucesso, que poderemos ter a chance de que a lei abstrata que serve de substrato à noção de cidadania seja uma realidade efetiva (Souza, 2006a, p. 129).

A leitura unilateral e descontextualizada do trabalho de Franco realizada por Souza, como argumento na próxima seção, termina retirando os elementos mais significativos da crítica da autora às interpretações dualistas que defendem a existência de uma diferença essencial entre centro e periferia que, fundamentalmente, é um dos principais objetivos dos trabalhos produzidos por Souza. O sociólogo, portanto, realiza uma leitura de Franco contra Franco, uma vez que a obra da autora é utilizada em sentido contrário ao seu objetivo ao produzir a tese sobre a velha civilização do café.

De Florestan, Souza utiliza a primeira parte da Revolução Burguesa no Brasil e o primeiro volume da Integração do Negro na Sociedade de Classes. Assim como realizado com Franco, a utilização dos trabalhos de Florestan tinha como objetivo corroborar a teorização sobre a modernização seletiva e a subcidadania, respectivamente, como veremos a seguir. Souza utiliza A Revolução Burguesa no Brasil para reforçar sua tese sobre o processo de modernização de fora para dentro, bem como seu caráter seletivo. Precisamente, Souza (2006a) faz um uso instrumental da obra de Florestan (2006). Assim o processo de Independência, ocorrido em 1822, representou a incorporação no Brasil do padrão do mundo ocidental moderno:

Florestan percebe, com clareza e agudeza impecáveis, que o ponto essencial neste contexto é a compreensão do 'padrão de civilização dominante a partir da transformação estrutural das formas econômicas, sociais e políticas fundamentais (Souza, 2006a, p. 130). 
Mesmo reproduzindo esse padrão civilizatório, a institucionalização que ocorreu entre nós teve um caráter desviante e incompleto devido ao déficit ético-religioso que fez com que o tradicionalismo fosse transplantado para a sociedade nacional, sendo fator decisivo para explicar as condutas e relações sociais existentes no âmbito rural.

Por conta da singular institucionalização do padrão civilizatório ocidental, o liberalismo narrado por Florestan (2006) não conseguiu formular, como nos casos europeu e norte-americano, expectativas de longo prazo para a sociedade com um alto grau de consciência e intencionalidade. Assim, não teríamos homogeneizado o tipo de personalidade e economia emocional burguesa como existentes nos países centrais (Souza, 2006a, p. 135). Esse desvio em relação à modernidade central ocorreria, por sua vez, pela permanência do tradicionalismo como elemento central da sociedade escravista e rural, como pode ser visto através da obra de Florestan ${ }^{15}$ :

Assim, até a derrocada do escravismo (1888) e do Império (1889), as novas forças e práticas sociais em ação desde o início do século XIX mostram-se ainda sob a lente de distinções estamentais da ordem anterior. É precisamente esse "déficit" de articulação que dá conteúdo à noção de Florestan de uma revolução burguesa "encapuzada”. Ela se produz molecularmente, capilarmente, em pequeno, no dia a dia e nas práticas cotidianas, mas sem a articulação consciente e de longo prazo de uma visão de mundo adequada a seus próprios interesses (Souza, 2006a, p. 133).

Depois de utilizar a Revolução Burguesa no Brasil para reforçar sua teorização sobre a modernização seletiva, Souza traz a leitura do clássico A Integração do Negro na Sociedade de Classes para

15 De fato, Florestan interpreta São Paulo como o ponto de partida da modernização brasileira, uma vez que em curto período tornou-se nossa maior metrópole. Todavia, essa excepcionalidade para por aí, pois mesmo o centro burguês por excelência ainda permanecia regido por uma lógica tradicionalista como era marca das outras regiões do Brasil. Se formos comparar seu argumento com um Schwartzman (1988), por exemplo, que coloca São Paulo como base da representação no lugar da cooptação existente no restante do Brasil, meu argumento fica bastante claro. 
sustentar de forma empírica sua teorização sobre a subcidadania. Ao se debruçar sobre a obra de Florestan, Souza procura construir uma interpretação crítica ao analisar o equívoco de se pensar os conflitos de classes como frutos de resíduos da ordem tradicional. Todavia, o sociólogo parte de uma leitura equivocada sobre o significado do tradicionalismo para a interpretação de Florestan Fernandes. Florestan (2008a, 2008b) não analisa o tradicionalismo como resíduo, ou seja, como elemento pertencente à ordem tradicional que estaria sendo solapado pelo processo de modernização.

O sociólogo paulista, todavia, aponta o tradicionalismo como elemento estruturante da ordem escravista e também da sociedade de classes, uma vez que fora responsável por gerar uma ordem social competitiva incompleta e distorcida quando comparada à congênere dos países centrais que teriam conseguido romper de forma plena com o antigo regime tradicionalista através da constituição de uma ordem social competitiva aberta "A integração do negro é uma análise sobre os limites da democracia no Brasil e pode ser alinhado à atualidade que põe em questão a concepção formal de justiça e de igualdade de condições sociais, política e culturais" (Cohn apud Botelho et al., 2018, p. 38). A citação acima demonstra que a tese dos resíduos não se sustenta, pois Florestan não acreditava que os elementos tradicionais que impediam a institucionalização plena da ordem competitiva e da democracia iriam ser derruídos com o aprofundamento do processo de modernização.

Ao construir sua tese sobre o capitalismo dependente, Florestan (2006) advoga que a junção do tradicionalismo ao moderno é um traço indissolúvel do capitalismo dependente, pois a unidade contraditória entre ambos só se encerraria com o término do próprio capitalismo existente na periferia. Para Florestan, portanto, a formação brasileira seria marcada pelo encontro reiterado em tradição e modernidade, mesmo que dinâmico e diverso (Botelho et al., 2018, p. 17).

De acordo com Souza, a reprodução do comportamento tradicional do negro foi um fator decisivo para sua inadaptação ao ambiente moderno e concorrencial da sociedade de classes nascente: 
Ao negro, fora do contexto tradicional, restava o deslocamento social na nova ordem. Ele não apresentava os pressupostos sociais e psicossociais que são os motivos últimos do sucesso no meio ambiente concorrencial (Souza, 2006a, p. 154).

Souza (2006a) argumenta que a questão central abordada por Florestan (2008a) é a organização psicossocial do negro como um pré-requisito fundamental para a participação com chances reais de êxito na sociedade capitalista. Faltava ao ex-escravo uma pré-socialização que o preparasse para a vida em uma sociedade capitalista, moderna e de classes, cuja estratificação não se daria mais por códigos tradicionais como o personalismo que, por sua vez, era traço estruturante na sociedade escravista (Souza, 2006a).

Assim, o tradicionalismo do negro torna-se o elemento central a explicar sua marginalização continuada que, na interpretação de Souza, seria generalizável para os dependentes formalmente livres de qualquer cor que viviam à margem do sistema escravista. Esse contingente não possuiria as condições psicossociais de personalidade para se adaptar ao trabalho livre e agir conforme os requisitos da sociedade competitiva (Souza, 2006a).

O comportamento tradicionalista e de razão essencialmente diversa daquele requerido pela sociedade moderna e de classes foi reproduzido pelos negros devido ao padrão familiar desorganizado: "A vida familiar desorganizada, aliada à pobreza, era responsável por um tipo de individualização ultra egoísta e predatória” (Souza, 2006a, p. 158). Em razão da reprodução secular deste padrão disruptivo e tradicionalista de desorganização familiar, foi gerada a ralé estrutural, que seria incapaz de incorporar a disciplina produtiva do capitalismo:

Ora, é precisamente o abandono secular do negro e do dependente de qualquer cor à própria sorte a "causa" óbvia de sua inadaptação. Foi este abandono que criou condições perversas de eternização de um “habitus precário”, que 
constrange esses grupos a uma vida marginal e humilhante à margem da sociedade incluída (Souza, 2006a, p. 160).

Apesar da sofisticação da análise e dos elementos inovadores trazidos para a compreensão da modernização brasileira e da desigualdade social, Souza repete o dualismo representado pela disjuntiva Brasil rural tradicional-Brasil urbano moderno presente na sociologia da inautenticidade. Esta é uma das armadilhas em que nossos intérpretes caem ao analisar o antigo regime sob o prisma do sistema escravista como instituição total.

Ademais, Souza termina seguindo Holanda em sua caracterização do Brasil agrário, escravista, patriarcal e personalista. É por conta dessa continuidade que defendo que Souza não se afastou completamente da sociologia da inautenticidade como defende ter feito, e não apenas por construir uma imagem da modernidade periférica que se constitui como desvio, falta e incompletude em relação aos países centrais, que faria com que não houvesse similitudes de conteúdo em relação às interpretações da sociologia da inautenticidade e a teorização de Jessé Souza.

Analiso a seguir o trabalho de Franco sobre os homens livres pobres em um sentido diferente daquele trabalhado por Souza, pois apresento uma leitura contextualizada de sua obra que inexiste na interpretação do sociólogo. Assim, procuro trazer elementos para apontar a complexidade do período escravista e demonstrar que o elemento moderno não foi resultante apenas do processo de reeuropeização, mas também das relações de produção que aqui foram constituídas. No final da seção, apresento algumas importantes questões trazidas por Cardoso $(2008,2010)$ que me auxiliarão à crítica a Jessé Souza. Com isso, procuro trazer elementos para questionar as teses centrais de Souza e aproximá-lo da sociologia da inautenticidade.

\section{Franco e a crítica ao tradicionalismo brasileiro}

Como argumentei acima, defendo que Jessé Souza retira o elemento de menor importância e ainda de uma forma distorcida 
da interpretação de Franco, que é o argumento da autora sobre a importância central da dominação pessoal. Como último ponto desta parte, gostaria de expor elementos da interpretação de Maria Sylvia de Carvalho Franco sobre o Brasil escravista e também as críticas feitas por ela em relação às interpretações produzidas pela Cadeira de Sociologia I da Faculdade de Filosofia, Ciências e Letras da Universidade de São Paulo (USP), bem como às leituras hegemônicas durante os anos 1950-1960. De acordo com Cazes (2014):

O alvo de suas críticas eram as interpretações "dualistas" da sociedade brasileira - aquelas que pensavam de forma disjuntiva os pólos "tradição" e "modernidade", ou "feudalismo" e "capitalismo" - que colocavam numa passado "atrasado" as peias para o pleno desenvolvimento da ordem moderna industrial. Problematizando os próprios termos da polarização "arcaico" versus "moderno", a autora desafiava tanto as leituras "ortodoxas" do marxismo etapista, quanto a sociologia da modernização de cunho estrutural-funcionalista, hegemônica nas Ciências Sociais da época (p. 116).

Franco (1997) trabalha com a noção de unidade contraditória para caracterizar o período escravista, uma vez que defende que não houve o domínio pleno dos elementos tradicionais e nem dos modernos, pois a organização econômica formada nos latifúndios tinha como objetivo tanto a produção dos meios de vida quanto de mercadorias voltadas para o mercado internacional. Nesse sentido, a interpretação de Franco assemelha-se à obra clássica de Caio Prado Junior (2000), que defende que o sentido da colonização era explorar recursos naturais em proveito do comércio europeu ${ }^{16}$. Cazes (2014) argumenta que Franco retoma a tese do sentido da colonização de forma particular. A singularidade de sua perspectiva

16 Assim com Franco, a intepretação de Caio Prado vai de encontro à dualidade rural-urbano: "As diversas características de uma organização social bastante diferente da europeia surgiram de um objetivo básico: fornecer produtos primários para a metrópole. A colônia, como totalidade social, se constituiria, portanto, a outra totalidade social, a metrópole." (Ricupero, 2009, p. 232). 
ocorre porque, ao caracterizar a gênese burguesa de nossa formação no período colonial, a interpretação de Franco radicaliza a relação entre capitalismo e escravidão existente na obra de Caio Prado (Cazes, 2014, p. 122).

Para Franco (2011), a escravidão e a violência eram funcionais ao capitalismo. Nesse sentido, e aliadas à maior complexidade que a produção escravista passou a ter no século XVIII, ligada diretamente ao mercado internacional, a autora vê como problemática a conceituação do modo de produção a partir do escravo, ou seja, da escravidão como instituição total como fazem Freyre, Florestan, Holanda e Jessé Souza.

Franco (2011) afirma que a Faculdade de Filosofia contribuiu para o desenvolvimento do capitalismo no Brasil, pois os trabalhos que analisavam a sociedade escravista e o pré-capitalismo nela existente iluminaram de maneira silenciosa a racionalidade capitalista, além dos trabalhos feitos no CESIT, "de onde saíram os estudos sobre o empresariado e sobre a classe operária, projetados sobre o pano de fundo do capitalismo clássico, e tributários do 'atraso' brasileiro" (Franco, 2011, p. 176). As interpretações construídas na FFCL foram responsáveis por construir uma justificação intelectual que acabou desaguando no chamado "milagre brasileiro". De acordo com Botelho (2013): "Sua obra sociológica, antes problematiza que corrobora alguns dos pressupostos empíricos, históricos e teóricos dos trabalhos do seu orientador Florestan Fernandes e de seu grupo como um todo" (p. 357).

A autora nos dá a possibilidade de observar como a formação particular do sistema capitalista global pode gerar formações modernas para além daqueles advindas dos países centrais. Ou, nas palavras de Franco, seriam analisadas as peculiaridades da formação capitalista brasileira dentro do sistema capitalista global. O cuidado da autora com a dimensão histórica e a inexistência em seu argumento dos pressupostos caros à teoria da modernização a fazem questionar duramente a utilização das categorias da sociologia da dominação weberiana para analisar o suposto tradicionalismo da sociedade brasileira como fazem Florestan (2008c) e Cardoso (2003): 
Procurei usar os conceitos de relação comunitária, de autoridade tradicional e de sociedade estamental conforme os requisitos dos tipos ideais, para esclarecer sua inadequação à sociedade brasileira e, ao mesmo tempo, ressaltar a técnica defeituosa de generalização que tem levado à inapropriedade no uso desses conceitos. De passagem, quero apenas advertir que essa objeção não se resolve com o argumento da distância entre situações empíricas e conceitos puros. A referida inapropriedade vem de se esquecer que os tipos ideais, em que pese seu caráter formal, são construções teóricas que expõem o caráter singular dos fenômenos culturais. Nessa medida são históricos. São conceitos genéticos, cujo rigor supõe a observância dos nexos de sentido entre seus componentes, da configuração em que estão arranjados, com suas tendências essenciais e o princípio que as governa. A negligência desses requisitos transforma-os em conceitos classificatórios que meramente sumariam traços comuns a certos fenômenos empíricos (Franco, 1997, p. 15-6).

Por conta da análise a partir do modo de produção escravista, a sociedade brasileira terminou sendo considerada estamental, pois estruturada pelo tradicionalismo. Para Franco (2011, p. 176), os trabalhos que constituíram uma proposição dualista para criticar o pré-capitalismo e a sociedade escravista tinham como elemento implícito a iluminação da racionalidade civilizadora da modernidade: "Tradicional e moderno serviam para distinguir sociedades 'atrasadas' e sociedades 'avançadas' que constituem o começo e o fim de um processo de modernização" (Villas Bôas, 2014, p. 24). A partir de uma perspectiva estruturada pela historicidade, Franco desautoriza a reificação das categorias tradicional e moderno, que possuíam um caráter normativo e que também foram incorporadas de maneira acrítica (Botelho, 2013, p. 354).

De acordo com Franco (2011), o conceito de estamento foi utilizado como categoria classificatória e não como conceito histórico, 
pois tinha a função de distinguir a sociedade brasileira escravista do capitalismo como instância civilizadora:

Nem do ponto de vista teórico, nem da pesquisa histórica, sustenta-se a caracterização "estamental" da sociedade brasileira, mas este rótulo cumpriu a importante tarefa ideológica de separar o economicamente "irracional e improdutivo", o "socialmente violento e preconceituoso", o "politicamente reacionário", do moderno, do progressista, do último termo do milenarismo, ora escondido, ora confessado: o capitalismo como instância civilizadora. Sociedade escravista e estamental, de razão essencialmente diversa da sociedade de classes, do trabalho livre e da racionalidade capitalista: este é o quadro em que se entrincheirava a teoria da história brasileira (Franco, 2011, p. 173).

Portanto, não era no sentido exposto por Souza (2006a) que Franco defendeu que a dominação pessoal era um elemento central no Brasil escravista, pois a pessoalização demarcada pela socióloga era individualizada, ou seja, voltada para uma conduta moderna (Cazes, 2014). Como afirma Cazes (2014), dominação pessoal e dominação burguesa estavam entrelaçados na velha civilização do café através de um padrão autocrático de mando. Assim, a dominação pessoal relatada por Franco apenas possui inteligibilidade quando é relacionada à atividade lucrativa e ao interesse econômico que eram decisivos naquela sociedade. Portanto, a dominação pessoal estava relacionada diretamente com a lógica impessoal do capitalismo, pois o elemento considerado velho era funcional ao novo voltado para a acumulação capitalista. Desta forma, a junção entre esses dois elementos seria suficiente para demonstrar como construímos uma formação capitalista autêntica na periferia porque o sentido da produção aqui realizada não se diferia daquele existente nas sociedades do capitalismo originário. Por isso, defendo que Souza distorce o potencial interpretativo contido no trabalho 
de Franco, ao utilizá-lo para corroborar sua teorização sobre o caráter tradicional da dominação pessoal no Brasil agrário.

Franco tinha como objetivo defender a impropriedade da tese das resistências à mudança que preferiam acentuar a força dos elementos tradicionais: "[...] procurei esclarecer como o conjunto de elementos que formalmente poderiam ser identificados como tradicionais apenas se torna inteligível quando referido à produção lucrativa" (Franco, 2011).

Outro ponto muito importante para o questionamento do pretenso caráter tradicional da sociedade rural e escravista refere-se à organização interna das famílias pertencentes às camadas dominantes. Franco (1997) questiona a tese de que os senhores de terra teriam uma organização interna rígida o suficiente para reproduzir uma concepção estamental de vida:

Consideremos o padrão de organização da família tradicional brasileira, vigente entre as camadas altas da sociedade, até os fins do século XIX. Durante esse período em que tendeu para um padrão patriarcal de organização, a família brasileira apresentou uma dupla estrutura: um núcleo legal, composto do casal e seus filhos legítimos, e a periferia, constituída por toda sorte de servidores e dependentes. $\mathrm{O}$ casamento, longe de ser deixado à discrição das partes diretamente interessadas, decidia-se conforme ponderações impessoais e de acordo com os interesses da família enquanto grupo. $\mathrm{O}$ processo de seleção dos cônjuges deixa bem claro o quanto as uniões estiveram fundadas em considerações racionais de interesses. Completa-se esse quadro ao se indicar que, mediante alianças intrafamiliares, estabelecia-se uma intrincada, ampla e solidária rede de parentesco, integrando-se assim grandes grupos que constituíram um poderoso sistema de dominação socioeconômica. A família moldou-se dominantemente para realizar essa função ordenadora das relações sociais antes que para resolver problemas de ordem emocional ou sexual (Franco, 1997, p. 35). 
A partir da citação de Franco faço os seguintes questionamentos: se a organização patriarcal era fundada em interesses racionais e impessoais, como a modernização brasileira foi seletiva e voltada unicamente para o âmbito urbano? É sustentável a tese da dualidade entre rural e urbano? Ao contrário da interpretação de Souza, era a dimensão impessoal e racional do interesse que funcionou como elemento norteador para a formação familiar entre as camadas dominantes durante o período escravista que durou até o final do século XIX.

Franco (1997) refere-se à organização da produção do café através da ênfase nos seus tipos sociais característicos: o fazendeiro, o tropeiro e o vendeiro, estes últimos sendo os dependentes que estariam submetidos à dominação personalista e estritamente tradicional segundo a interpretação de Souza. Franco argumenta que a organização interna da fazenda foi realizada a partir de critérios de mercado, o que desautorizava a caracterização de tipo estamental. A diferença que existia entre as fazendas não se dava pela tradição e pelos valores estamentais, mas sim devido a critérios produtivos e de mercado, como o tamanho e a escala de produção. Assim, o mercado funcionava como elemento definidor das ações que nelas eram tomadas (Franco, 1997).

Através da análise desses tipos sociais, que representavam a diferenciação social existente, é possível observar como a sociedade escravista possuía uma organização dinâmica que auxiliou mais uma vez a autora a questionar a interpretação da sociedade escravista como rígida, estamental e, portanto, estritamente tradicional. A dependência pessoal não seria a prova da força da dominação estamental e tradicionalista, porque estava pautada pelo interesse econômico.

O elemento moderno era o fator estruturante daquela sociedade, uma vez que tinha papel crucial desde a organização familiar dos grupos dominantes, as relações entre os homens livres e dos fazendeiros com os escravos.

Franco (1997) demonstra como as economias de mercado e de subsistência foram realidades correlatas durante o século XIX, 
coexistindo como unidades contraditórias. Aliás, esse seria o traço principal a caracterizar a realidade brasileira escravista que, apesar de ter no moderno interesse econômico o seu elemento norteador, tinha dentro de si fatores que coexistiam de maneira funcional e contraditaria, como a dominação pessoal, a escravidão, o desvirtuamento do poder público em interesse privado e o arbítrio através da violência estrutural. Bem, todos esses elementos são interpretados como fatores impeditivos à plena realização do capitalismo. Para a autora, todavia, esses fatores eram funcionais ao desenvolvimento do capitalismo durante o período escravista da história brasileira.

A análise de Franco (1997) alia teoria social com análise histórica densa para defender ao longo do trabalho a impropriedade em se caracterizar o Brasil escravista como pré-moderno e a inadequação em compreendê-lo, a partir da escravidão, como um sistema social capaz de explicar todas as relações sociais e de produção. Como lembra Botelho (2013), Franco produziu a crítica teórica mais detalhada e consistente das visões disjuntivas entre tradição e modernidade que eram centrais às teorias da modernização de seu tempo.

Ao contrário de Souza, a interpretação de Franco trouxe a possibilidade de questionar a leitura ainda hegemônica sobre o Brasil escravista, que é interpretado como estamental, personalista e, portanto, estruturado pelo tradicionalismo ${ }^{17}$. Levando-se em consideração o endereçamento das críticas feitas pela socióloga podemos observar não apenas a relevância de suas teses, como também o equívoco da leitura de sua obra clássica realizada por Jessé Souza.

Como último ponto nesta seção, trago alguns elementos de interpretação de Adalberto Cardoso $(2008,2010)$ que me auxiliam a sustentar empiricamente a crítica à obra de Souza. Cardoso constrói uma interpretação multifatorial e consistente para

17 Como defende Tavolaro (2014), construímos nossa singularidade a partir da comparação com um discurso sociológico que define a modernidade como uma ordem composta pela racionalização, secularização, complexificação social e separação estrita em público e privado. É por conta disso que nossos principais intérpretes, apesar de observarem as flagrantes modificações na realidade brasileira, continuam interpretando nossos conflitos como resultantes da herança tradicionalista que nos deixa em posição essencialmente diferente dos países centrais que, por sua vez, teriam vencido plenamente o"antigo regime"tradicionalista e seriam material e simbolicamente superiores. Assim, constituiríamos um verdadeiro hiato em relação aos países cêntricos. 
explicar o regime escravista que me permite conectá-la à interpretação de Franco e, ao mesmo tempo, trazer elementos para questionar as teses centrais de Souza.

Cardoso (2010) defende que temos uma herança escravocrata marcada por alguns elementos centrais, quais sejam: ética do trabalho degradado; a imagem depreciativa do elemento nacional; a indiferença moral das elites quanto às necessidades da maioria; e uma hierarquia social de grande rigidez no topo, que fez com que as aspirações de ascensão social não existissem no horizonte dos setores subalternos.

Assim como Souza, Cardoso (2010) defende que a sociabilidade capitalista possui uma pesada herança do sistema escravista. Se os autores concordam sobre o peso da escravidão para a formação da sociedade de classes profundamente desigual, eles divergem sobre a imagem que constroem do sistema escravista e da herança deixada por ele.

Cardoso (2008) argumenta que existiram diferentes tipos de escravidão no Brasil, o que fez com que o ex-escravo também fosse mão de obra ativa. A transição para o trabalho livre que ocorreu em São Paulo, e que é central para a teorização de Souza, deve ser pensada como uma exceção ao que ocorreu no restante do Brasil, uma vez que a imigração teve um papel decisivo apenas em São Paulo. Cardoso (2010), portanto, diverge da explicação sãopaulocêntrica que é central para Souza construir sua tese sobre a ralé estrutural. Segundo Cardoso (2008), em outras regiões como Minas Gerais, Ceará, Pernambuco ou Maranhão, as funções agrícolas foram sendo assumidas por ex-escravos, seus descendentes e brasileiros livres.

A análise da escravidão a partir da identificação de regimes diferentes possibilitou a crítica à interpretação do Brasil-colônia como um território marcado de forma exclusiva por plantations monocultoras, cuja estrutura social seria marcada pela simplicidade, como está presente na interpretação de Freyre e que é reproduzida acriticamente por Souza: 
Escravos e donos de terras eram sem dúvida as classes centrais, mas elas conviviam com uma infinidade de outros grupos, também importantes para a sustentabilidade da ordem escravista: artesãos e artífices nos ofícios urbanos, comerciantes, tropeiros, criadores de animais, pequenos produtores de víveres para o mercado interno, mercadores de escravos, financistas, milicianos, construtores, feitores, pequeno proprietários rurais que produziam para si mesmos... Mais ainda, a plantation, grande extensão de terra ocupada por monocultura empregando centenas de escravos, foi exceção no período colonial e depois (Cardoso, 2010, p. 58-9).

Cardoso (2008, p. 75) defende que a identificação de diferentes regimes de escravidão possibilitou observar que houve, desde o século XVIII, a convivência entre o trabalho escravo e diversos tipos de trabalho não escravo. Segundo Cardoso (2008, p. 75): "Homens livres ou libertos se avolumavam ao longo dos séculos, obtendo meios de vida cujas formas perderam cada vez mais o cariz intersticial que lhes atribui a literatura até meados dos anos 1980".

Assim, a crítica de Franco sobre as análises que interpretam a escravidão como uma instituição total, ou seja, a partir das plantations monocultoras e da consequente relação senhor-escravo mostra-se uma crítica acertada, pois se simplificarmos a estrutura social da maneira como é feita sob a perspectiva acima citada apenas observaremos o tradicionalismo e uma razão essencialmente diversa do capitalismo como elemento estruturante e dominante em todas as relações sociais.

Portanto, não foi a inadaptação ao trabalho livre que terminou sendo o elemento central para o não reconhecimento da maioria da população como agente produtivo e cidadão na sociedade de classes, visto que o exemplo de São Paulo não foi a regra no restante do país. Desta forma, inexiste sustentação empírica para defender a tese da ausência das precondições para atender às demandas de Estado e mercado como o fator último da exclusão vista como 
ausência de personalidade moderna, ou seja, a tese da inadaptação à sociedade capitalista, competitiva e de classes em todo Brasil.

Seguindo a explicação multidimensional de Cardoso, a rigidez da estrutura social brasileira e sua abissal desigualdade social podem ser pensadas a partir do antiliberalismo de nossas elites que impactou de forma decisiva suas práticas e visões de mundo, que se desdobrou em uma ética de desvalorização do trabalho braçal e do não reconhecimento da grande parcela da população brasileira como cidadão trabalhador.

\section{Conclusão}

Como argumentei no início deste artigo, Jessé Souza possui grande importância entre nossos intérpretes contemporâneos, pois interpelou criticamente as tradicionais imagens culturalistas e essencialistas do Brasil, produziu uma grande interpretação teórica em um momento de especialização das ciências sociais (Werneck Vianna, 2004b) e defendeu de forma sistemática o caráter essencialmente moderno de nossos dilemas.

Os méritos se tornaram ainda maiores quando o sociólogo criticou a tese defendida no primeiro mandato do Presidente Luís Inácio Lula da Silva (PT) pelo economista Marcelo Nery, então presidente do Instituto de Pesquisas Econômicas Aplicadas (IPEA), de que o Brasil teria constituído uma nova classe média. Na verdade, como defende Souza (2010), o Brasil produziu uma nova classe trabalhadora precarizada e que havia conseguido romper com o círculo de ferro no qual está enredada a ralé estrutural.

Além da crítica à tese de Nery, o trabalho de Souza (2010) sobre os batalhadores representou uma apropriação crítica de sua teorização sobre a subcidadania que, por sua vez, não dava possibilidades à ralé estrutural de ascensão social devido à reprodução geracional de sua condição de classe. Souza $(2016,2017)$ também tem se engajado de maneira firme na denúncia do golpe parlamentar (Santos, 2017) que retirou a presidente Dilma Rousseff do poder, em 2016, e dos interesses que o nortearam juntamente com uma crítica severa à Operação Lava Jato. Estes elementos 
demonstram a importância da obra de Souza para a compreensão crítica de nossos dilemas mais importantes.

Mesmo com todos os méritos, a obra de Souza possui problemas significativos que necessitam ser tematizados, como sua relação com as interpretações culturalistas clássicas do Brasil, das quais ele advoga ter se afastado completamente. Como defendi durante o artigo, Souza fica à sombra da sociologia da inautenticidade, como afirma Tavolaro (2005), porque sua teorização reproduz o dualismo que é elemento decisivo para a reprodução da imagem distorcida, desviante e incompleta frente aos países centrais. Outro elemento que liga Souza à sociologia da inautenticidade é a reprodução do nacionalismo metodológico, uma vez que o campo empírico para a construção da modernidade periférica é o Brasil, o que termina reforçando as características brasileiras. A interpretação construída neste artigo, portanto, sistematiza e aprofunda a tese de Tavolaro sobre a relação de Souza com os autores que o sociólogo critica.

Caso não tivesse reproduzido uma leitura distorcida da obra Franco (1997), Souza teria condições de fugir do dualismo e, ao mesmo tempo, formular uma interpretação baseada na totalidade, ou seja, a análise do sistema capitalista a partir de uma perspectiva global (Cazes, 2014). Como consequência, poderia observar que a racionalidade também estava presente como instância decisiva das relações sociais no Brasil agrário e escravista. Desta forma, acredito que o sociólogo teria condições efetivas de se afastar plenamente da sociologia de inautenticidade. Esse afastamento pleno ocorreria porque a interpretação de Franco nos traz a possibilidade de construir uma narrativa moderna do caso brasileiro marcado por um efetivo patamar de autenticidade, pois seríamos regidos por valores e interesses modernos como ocorrem nos países centrais, mesmo que sua institucionalização possua particularidades nacionais demarcas pela contingência histórica.

Portanto, mesmo com as contribuições de Jessé Souza, acredito que, na formação brasileira, o processo de modernização e a desigualdade social seguem como questões em aberto para nossos intelectuais. 


\section{Referências}

ARAÚJO, Ricardo Benzaquen de. (1994) Guerra e paz: Casa Grande \& Senzala e a obra de Gilberto Freyre nos anos 1930. São Paulo: 34.

BASTOS, Elide Rugai (2006). As criaturas de Prometeu - Gilberto Freyre e a formação da sociedade brasileira. São Paulo: Global.

BASTOS, Elide Rugai. (2013). "A Construção do debate sociológico no Brasil". Ideias, vol. 4, p.287-300.

BRAGA, Ruy. (2017). Pode o subalterno lutar? Livro de Jessé Souza sobre a elite do atraso falha ao desprezar a capacidade de mobilização política das massas populares. Disponível em: http://revista451.com.br/conteudos/visualizar/Pode-osubalterno-lutar. Acessado em 10/01/2018.

BOTELHO, André. (2013). "Teoria e história na sociologia brasileira: a crítica de Maria Sylvia de Carvalho Franco", Lua Nova, vol. 90, p. 331-366.

BOTELHO, André et al. (2018). "Florestan Fernandes entre dois mundos: entrevista com Elide Rugai Bastos, Gabriel Cohn e Mariza Peirano". Sociologia e Antropologia, vol. 08, p. 15-43. BOURDIEU, Pierre (2009). O senso prático. Petrópolis: Vozes. CANDIDO, Antonio. (2010) "O significado de Raízes do Brasil". In: HOLANDA, Sérgio. Raízes do Brasil. 26a ed., São Paulo: Companhia das Letras.

CARDOSO, Adalberto (2008). "Escravidão e sociabilidade capitalista”. Novos Estudos, n. 80, p. 71-88.

CARDOSO, Adalberto (2010). A Construção da sociedade do trabalho no Brasil: uma investigação sobre persistência secular das desigualdades. Rio de Janeiro: FGV.

CARDOSO, Fernando Henrique (2003). Capitalismo e escravidão no Brasil meridional: o negro na sociedade escravocrata do Rio Grande do Sul. Rio de Janeiro: Civilização Brasileira.

CAZES, Pedro Faria (2014). "Passagens para o capitalismo: a sociologia histórica de Maria Sylvia de Carvalho Franco". Crítica e sociedade: revista de cultura política, vol. 4, n. 2, p. 114-138. 
DELGADO, Gabriel Estides (2017). “Jessé Souza - A tolice da inteligência brasileira: ou como o país se se deixa manipular pela elite", Estudos de Literatura Brasileira Contemporânea, n. 50, p. 514-522.

DAMATTA, Roberto (1981). Carnavais, malandros e heróis. Rio de Janeiro: Jorge Zahar Editor.

FAORO Raymundo. (2008). Os Donos do Poder: formação do patronato político brasileiro. $4^{\mathrm{a}}$ ed. São Paulo: Globo.

FELDMAN, Luiz. (2013). "Um clássico por amadurecimento: Raízes do Brasil." Revista Brasileira de Ciências Sociais, vol. 28, n. 82, p. 119-139.

FERNANDES, Florestan (2006). A Revolução burguesa no Brasil.5 ${ }^{\mathrm{a}}$ ed. São Paulo: Globo.

FERNANDES, Florestan (2008). A integração do negro na sociedade de classes: ensaio de interpretação sociológica. São Paulo: Globo, vol. I.

FERNANDES, Florestan (2008b). A integração do negro na sociedade de classes: ensaio de interpretação sociológica. São Paulo: Globo, vol. II.

FERNANDES, Florestan (2008c). Brancos e negros em São Paulo. São Paulo: Global.

FRANCO, Maria Sylvia de Carvalho (1997). Homens livres na ordem escravocrata. São Paulo: Unesp.

FRANCO, Maria Sylvia de Carvalho. (2011) [1981] "Entrevista com Maria Sylvia de Carvalho Franco”. Marília, Trans/Form/ Ação, vol. 4, p. 5-14.

FREYRE, G., (2005). Casa Grande \& Senzala: formação da sociedade brasileira sob o regime de economia patriarcal. 50a ed. São Paulo: Global.

FREYRE, Gilberto (2006). Sobrados e Mocambos. 16a ed., Rio de Janeiro: Global.

HOLANDA, Sérgio Buarque. (1995). Raízes do Brasil. 26a edição. São Paulo: Companhia das Letras. 
LAMOUNIER, Bolívar (1977). "Formação de um Pensamento Político Autoritário na Primeira República”. In: História Geral da Civilização Brasileira. Tomo III, Volume 2 (Sociedade de Instituições). São Paulo: Difel, p. 343-374.

LEAL, Edilene M.C. \& MATOS. Silvia M.S. (2016) Marcelo Neves e Jessé Souza: uma recaída na interpretação de modernidade universal? Trabalho apresentado no ST22 do $40^{\circ}$ Encontro Anual da Anpocs, p.1-30. Acessado em 10/03/2017.

LYNCH, C. (2013). Por que pensamento e não teoria? A imaginação político-social brasileira e o fantasma da condição periférica (1880-1970). Dados - Revista de Ciências Sociais, Rio de Janeiro, vol. 56, n. 4, p. 727-767.

LYNCH, C. (2016). Cartografia do pensamento político brasileiro. Revista Brasileira de Ciência Política, Brasília, n. 19, p. 75, p. 119. MARTINS, Maro Lara. (2014). Entre a Cultura e a Política: "A Sociologia Modernista dos Anos 1930". Revista de Estudos Políticos, n. 2, vol. 5, p. 583-599.

MATA, Sergio da. (2018) "A viagem redonda de Jessé Souza". Sociologias, ano 20, n. 47, p. 424-437.

PERLATTO, Fernando \& LIMA, Pedro. (2009) "Habermas e a teoria sociológica brasileira: Um estudo sobre as leituras críticas de Jessé Souza e Sergio Costa". Teoria e Cultura, n. 1e 2., vol. 4, p. 25-40.

PRADO JUNIOR, Caio (2000). Formação do Brasil contemporâneo: colônia. São Paulo: Publifolha.

RIBEIRO, Marcos Abraão (2017). "O golpe de 2016 e os dilemas do Brasil contemporâneo: as interpretações de Jessé Souza e José Maurício Domingues em perspectiva comparada". Terceiro Milênio: Revista Crítica de Sociologia e Política, n. 1, vol. 9, p. 15-51.

RICUPERO, Bernardo (2009). "Caio Prado e o lugar do Brasil no mundo". In: BOTELHO, André e SCWARCZ, Lília (Org.). Um enigma chamado Brasil: 29 intérpretes e um país. São Paulo: Companhia das Letras. 
SANTOS, Wanderley Guilherme (2017). A democracia impedida: o Brasil o século XXI. Rio de Janeiro: FGV.

SELL, Carlos Eduardo (2007). "Leituras de Weber e do Brasil: da política à religião, do atraso à modernidade”. Ciências Sociais Unisinos, n. 43, vol. 3, p. 241-248.

SCHWARTZMAN, Simon (1988). Bases do autoritarismo brasileiro. $2^{\text {a }}$ ed. São Paulo: Campus.

SOUZA, Jessé (1998). "A ética protestante e a ideologia do atraso brasileiro". Revista Brasileira de Ciências Sociais, v.13, n. 38, p.1-20. SOUZA, Jessé (1999) "A ética protestante e a ideologia do atraso brasileiro". SOUZA, Jessé (Org.) O malandro e o protestante: a tese weberiana e a singularidade cultural brasileira. Brasília: UnB. SOUZA, Jessé (2000). A modernização seletiva: uma reinterpretação do dilema brasileiro. Brasília: UnB.

SOUZA, Jessé. (2001). "A sociologia dual de Roberto DaMatta: descobrindo nossos mistérios ou sistematizando nossos autoenganos". Revista Brasileira de Ciências Sociais, n.16, vol. 45, p. 48-67.

SOUZA, Jessé (2005). "Raça ou classe? Sobre a desigualdade brasileira. Lua Nova, n. 65, p. 43-69.

SOUZA, Jessé (2006a). A construção social da subcidadania: para uma sociologia política da modernidade periférica. $2^{\mathrm{a}}$ ed. Belo Horizonte: UFMG.

SOUZA, Jessé (2006b). A invisibilidade da desigualdade brasileira. Belo Horizonte: UFMG.

SOUZA, Jessé (2009). A ralé brasileira: quem é e como vive. Belo Horizonte: UFMG.

SOUZA, Jessé (2010) Os batalhadores brasileiros: nova classe média ou nova classe trabalhadora? Belo Horizonte: UFMG.

SOUZA, Jessé (2015). A tolice da inteligência brasileira ou como o país se deixa manipular pela elite. São Paulo: LeYa.

SOUZA, Jessé (2016). A radiografia do golpe: entenda como e por que você foi enganado. São Paulo, LeYa.

SOUZA, Jessé (2017). A elite do atraso: da escravidão à Lava Jato. São Paulo, LeYa. 
SOUZA, Jessé (2018). Subcidadania brasileira: para entender o país para além do jeitinho brasileiro. São Paulo: Leya.

TAVOLARO, Sergio (2005). "Existe uma modernidade brasileira? Reflexões em torno de um dilema sociológico brasileiro". Revista Brasileira de Ciências Sociais, vol. 20, n. 59, p. 5-22.

TAVOLARO, Sérgio (2014). "A tese da singularidade brasileira revisitada: desafios teóricos contemporâneos". Dados - Revista de Ciências Sociais, vol. 57, n. 3, p. 633-73.

VILLAS BÔAS, Glaucia (2006). Mudança provocada: passado e futuro no pensamento social brasileiro. Rio de Janeiro: FVG.

VILLAS BÔAS, Glaucia (2014). "A recepção controversa de Max Weber no Brasil (1940-1980)". Dados - Revista de Ciências Sociais, vol. 57, n.1, p. 5-33.

WEFFORT, Francisco. (2003). O populismo na política brasileira.

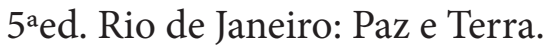

WEGNER, Robert (1999). "Os Estados Unidos e a fronteira na obra de Sérgio Buarque de Holanda”. In: SOUZA, Jessé. (Org.). O Malandro e o Protestante: a tese weberiana e a singularidade cultural brasileira. 1ed. Brasília: UnB.

WEGNER, Robert (2009) "Caminhos de Sérgio Buarque de Holanda”. In: BOTELHO, André e SCWARCZ, Lília (Org.). Um enigma chamado Brasil: 29 intérpretes e um país. São Paulo: Companhia das Letras.

WERNECK VIANNA, Luiz Jorge (1999) "Weber a Interpretação do Brasil”. Novos Estudos, n. 53, p. 33-47.

WENERCK VIANNA, Luiz Jorge. (2004a) "Americanistas e iberistas: a polêmica de Oliveira Vianna com Tavares Bastos”. In: WERNECK VIANNA, Luiz Jorge. A revolução passiva: iberismo e americanismo no Brasil. Rio de Janeiro, Revan.

WENERCK VIANNA, Luiz Jorge. (2004b) "A institucionalização das ciências sociais e a reforma social: do pensamento social à agenda americana de pesquisa”. In: WERNECK VIANNA, Luiz Jorge. A revolução passiva: iberismo e americanismo no Brasil. Rio de Janeiro, Revan. 


\section{Resumo}

Este artigo tem como objetivo questionar a ruptura de Jessé Souza com a sociologia da inautenticidade, representada pela obra de Sérgio Buarque de Holanda. O trabalho de Souza foi fundamental para demarcar a insuficiência das grandes interpretações culturalistas e essencialistas do Brasil contemporâneo, que nos interpretam como pré-modernos e completamente inferiores aos países modernos como os Estados Unidos. Com sua teorização, Souza trouxe uma importante contribuição para, a partir da periferia, também produzir teoria sociológica. Mesmo assim, defendo que Souza repete o dualismo rural (tradicional) - urbano (moderno) que é crucial para o autor permanecer à sombra da sociologia da inautenticidade e continuar reproduzindo, assim, a imagem do Brasil como incompletude, desvio e falta quando comparado aos países centrais, como ocorre com a interpretação de Holanda criticada pelo sociólogo.

Palavras-chave: Jessé Souza, modernização seletiva, subcidadania, sociologia da inautenticidade, dualismo.

\section{Abstract}

This article aims to question the rupture of Jessé Souza with the sociology of inauthenticity, represented by the work of Sérgio Buarque de Holanda. Souza's work was fundamental to demarcate the insufficiency of the great culturalist and essentialist interpretations of contemporary Brazil, which interpret us as pre-modern and completely inferior to modern countries such as the United States. With his theorization, Souza made an important contribution to, from the periphery, also to produce sociological theory. Nonetheless, I argue that Souza repeats rural dualism (traditional)- urban (modern) that is crucial for the author to remain in the shadow of the sociology of inauthenticity and continue to reproduce Brazil's image as incompleteness, diversion and absence when compared to the central countries, as it happens with the interpretation of the Netherlands criticized by the sociologist.

Keywords: Jessé Souza, selective modernization, sub-citizenship, sociology of inauthenticity, dualism.

Recebido em 28 de fevereiro de 2019

Aprovado em 25 de julho de 2019 